Historic, Archive Document

Do not assume content reflects current scientific knowledge, policies, or practices. 

RETURN TQ POSE SECTION OENOY

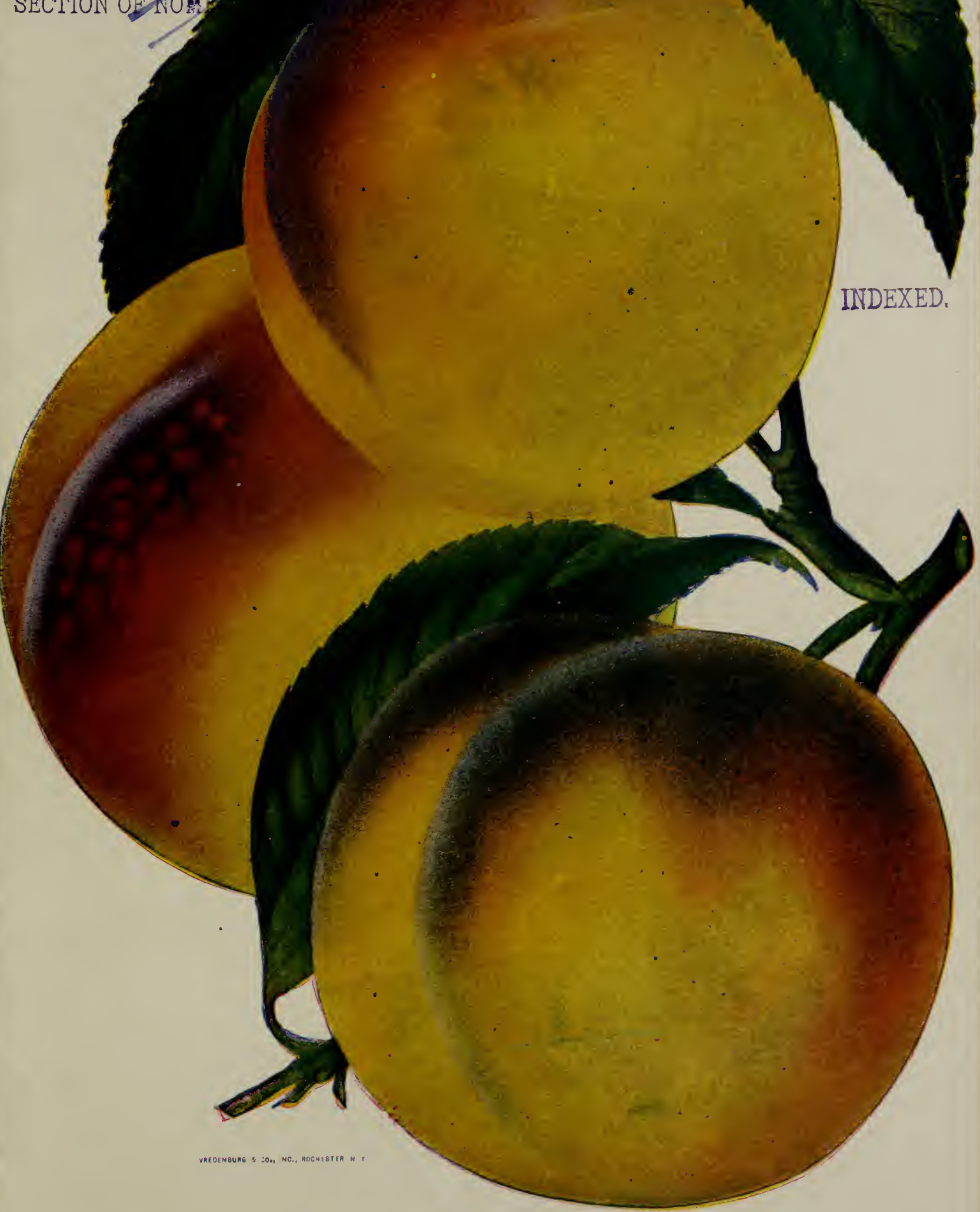

LAKE SHORE NURSERIES On Lake Erie $\quad$ GIRARD, PA. 


\section{DIRECTIONS FOR TRANSPLANTING}

\section{CARE OF STOCK, ETC.}

Care of Stock on Arrival-Upon arrival of box or package place it in a shed, barn or cellar away from sun, take off the cover and thoroughly wet down with water and allow it to stand twelve hours or over night before removing the stock. (Excepting Raspberry tips and Strawberry plants, which should be at once heeled in soil.) Then make ready a trench fourteen inches deep and as soon as stock is removed from the package heel it in this trench, giving the roots plenty of mellow soil, well pressed down with the feet. If soil is dry moisten it with water after heeling in; the trees are then ready for planting and should only be taken out as needed. If trees or plants are very dry or shriveled at once bury them, root, body and branch, in very moist soil, well pressed down, and leave them for four to six days, when they will be found as plump and fresh as when first dug. If frozen, no water should be applied, but they should at once be buried in earth until all frost is out, and they will nut be injured.

Soil-Should be high and well drained, either natural or artificial, by means of tile drainage. Low land continually saturated with water will not do. It must be deeply plowed and in perfect condition. Never plant fruit trees in sod. The land should be in as good condition as for a crop of wheat or potatoes. If poor, manure thoroughly or plow in heavy crops of clover beforehand. In the fall give the land a covering of rye, clover or veitches to be plowed under early the following spring. If any crops are grown in the young orchard let it always be a hoed crop and plant nothing nearer than four feet each side of the tree. If you want trees to grow well, be vigorous and strong, you must give them plenty of food and good cultivation until August 1st, when all cultivation should cease, to allow new wood to thoroughly ripen up before cold weather, which it will not do if kept growing by cultivation after that date.

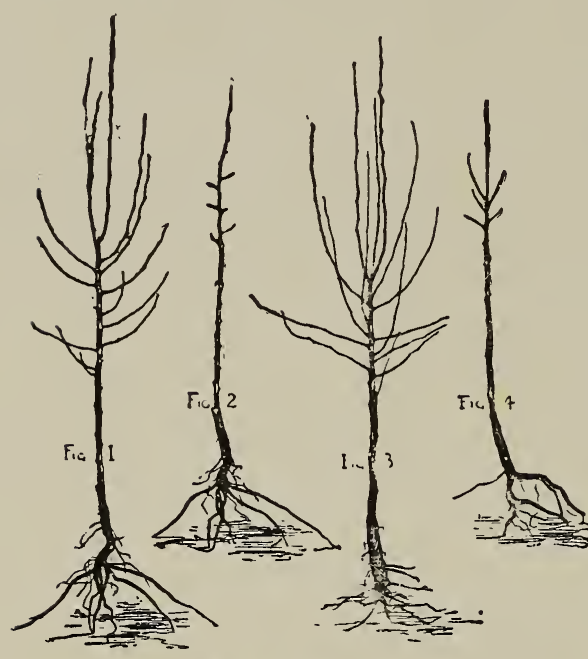

Figs. I and 3 show trees as the 7 come from the nursery, Figs. 2 and 4 show the same trees properly pruned back for plan`ing.
Pruning-Is most important. In digging, more or less roots are lost of necessity. The top then must be cut back to even up for loss of roots. Leave only four or five branches and cut these back to four or five buds. Peaches are best trimmed to a whip or nearly so, and cut back to not more than 2 or 3 feet high. Remove all broken roots and branches and with a sharp knife cut the ends of the roots back to clean, healthy wood. This helps to start root growth. Fibers occupy the relation to the roots that leaves do to the branches, they die and are succeeded by another lot yearly, and are of no more value to the roots than dead leaves would be to the branches. Hence, you want plenty of large and small hard and clean roots, and the less fibers the better.

Planting-Make holes plenty large, so as not to crowd the roots. Use surface soil for filling in, and plant as firm as possible, pressing soil well down with the feet. See that roots are well spread out and soil firmly around themdon't hurry the job, do it well, and success is certain. After planting, each tree should be well mulched for two or three feet out with coarse manure. This prevents drying and is better than watering. The trees should not be long exposed to sun and air. Never put any manure in the holes with the roots, it causes decay.

Cultivation-We don't believe in allowing orchards in sod. You can't expect to get a paying crop without cultivation. Cultivate the orchard and keep it cultivated up to August 1st. The finest and most productive orchards we have ever seen are cultivated every ten days or two weeks during spring. The best fertilizer for a young orchard is a green crop plowed in every spring, or liberal manuring until trees are well grown and begin to fruit, after that, wood ashes or potash, with an occasional green crop plowed in, are better than barnyard manure and will supply all that is needed.

Young, Healthy Stock is much superior to old, or very large trees. Two or three year old trees are more apt to live, are easier handled and can be trimmed or shaped to any desired form, and will outstrip older stock in growth. Practical fruit growers always plant young trees.

Spraying-A complete and up-to-date calendar with formulas will be sent free to our customers on request. 


\section{ILLUSTRATED}

\section{DESCRIPTIVE CATALOGUE}

$-\infty$

\section{Fruit and Ornamental Trees,}

SMALL FRUITS,

\section{Vines, Roses, Shrubs,}

ETC., ETC.

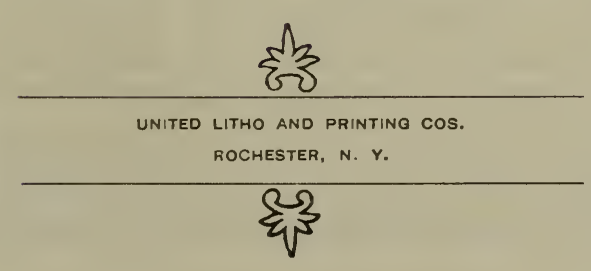




\section{PREFACE.}

WE take pleasure in presenting a new edition of our Descriptive Catalogue, caro fully revised and corrected by the addition of descriptions of new and promising sorts and the omission of such as greater experience and progress in horticulture and floriculture have proved no longer worthy of general dissemination.

We have not attempted a full and complete description of all varieties named,but shall be pleased to answer by letter any inquiries sent with stamp for reply, as to planting, cultivating, etc., and as to the most desirable sorts for planting in different localities, and for different purposes.

Nothing better illustrates the progress of our country, the advance in civilization its people are making, and the fact that they are learning to live better, than the greatly increased and continuing demand for nursery stock, both fruit and ornamental.

To the planter or purchaser of nursery stock, at least three things are indispen. sable; first, varieties true to name; second, healthy, vigorous well matured trees or plants; and third, careful and judicious packing, without which all may be los+.

We give the most careful scrutiny to the genuineness of varieties, endeavoring by all methods known to us, to protect our customers from error or imposition. By such careful and constant watching and attention, we are warranted in offering our stock as pure, and absolutely true to name.

Good cultivation-by which we mean keeping the ground sufficiently fertile and at all time mellow and free from weeds, together with thorough drainage, either, natural or artificial-is absolutely necessary to success. This, with judicious pruning, and proper selection of varieties, suitáble for the locality, will, in nearly all sections of the country, produce gratifying results.

The soil hereabout being of a character best suited to produce the healthiest conditions of growth, that solid, firm texture of wood, with abundant fibrous roots, so necessary to successful transplanting, we are enabled to offer the choicest nursery stock to planters with entire confidence.

We give to our packing and shipping careful personal supervision, and still further to protect our patrons, as well as ourselves, against loss in this direction, we employ the most skilled and competent hands to assist us.

We aim to keep fully abreast of enlightened and cultivated taste in the introduction of new and valuable varieties of fruit, and novelties and valuable acquisitions in ornamentals; accepting with pleasure everything that has real merit, we shall with equal readiness discard and discountenance the sale of worthless humbugs.

By careful consideration of the wants of our trade and faithful attention to business, we are confident we shall continue to merit and receive a liberal share of the patronage of lovers and buyers of choice fruits and ornamentals. 


\section{Apples.}

Our list embraces a careful selection of the best for the several seasons and those that have proved worthy of general cultivation. Those starred $\left(^{*}\right)$ are the Russian and hardier varieties.

\section{SUMMER.}

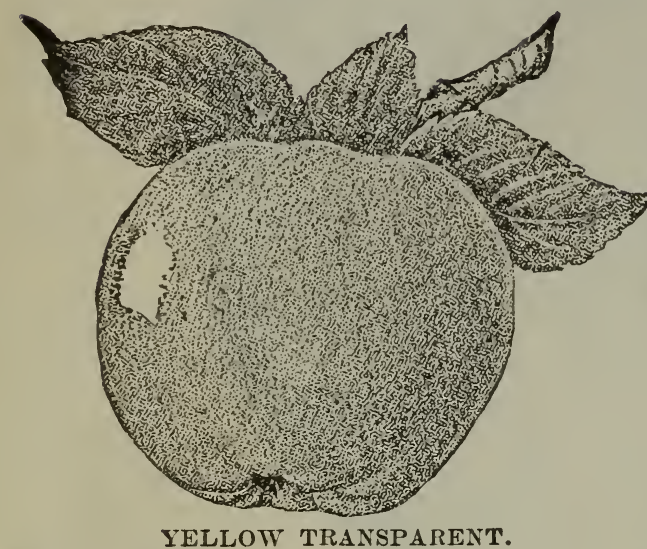

*Early Colton-Medium, yellowish-white. Ripens before Early Harvest.

Early Harvest-Medium, pale zellow, fine flavor sub-acid; very productive. July.

Early Strawberry-Medium, deep red, tender, with mild sub-acid flavor. July to September.

Golden Sweet-Large, yellow; fine sweet apple. August and September.

Keswick Codlin-Large, oblong, pale yellow, witk mild fine flavor. July to Uctober.

*Primate-Medium, pale yellow, with blush or sunny side; tender and good. Excellent for dessert. August and September.

*Red Astrachan-Large, crimson, juicy, with ricb sub-acid flavor. Bears early; hardy. July.

Red June-Medium size, deep red; productive.

Sops of Wine-Deep red, flesh white, sub-acid, fine eating. August.

Sweet Bough-Large, pale green, flesh sweet, with rich flavor. July to August.

*Tetofsky-Medium, yellow, striped with red and heavy bloom; juicy and acid; very hardy August.

-Yellow Transparent-A Russian apple of splendid quality. The hardiest and finest early sum mer apple grown. Ten days earlier than Early Harvest. Fruit large, pale yellow, sub acid; a very early bearer and entirely hardy. This variety is one of the best market sorts

\section{AUTUMN.}

-Alexander-Large, deep crimson, sub-acid; hardy and productive; poor quality. Fall.

Chenango Strawberry (Sherwood's Favorite)Large, oblong, striped red, flesh white, tender, sub-acid, good; very productive. Sept.

- Duchess of Oldenburg-A large, beautiful Russian apple, round, streaked red on yellow ground; tender, juicy, very acid. Fine for cooking. Bears early; productive. Sept.

* Fameuse (Snow)-Medium, deep crimson, flesh very white, tender, crisp and juicy, subacid. A popular dessert apple. October.

fall Pippin-Very large, yellow, rich and juicy, delicious, sub-acid. October and November.

Gravenstein-Very large, round, yellow, flesh tender, juicy, crisp, aromatic, sub-acid; first quality. September.

Haas-Large, flat, yellowish-green, nearly covered with dull red; sub-acid; tree hardy and vigorous. September to November.

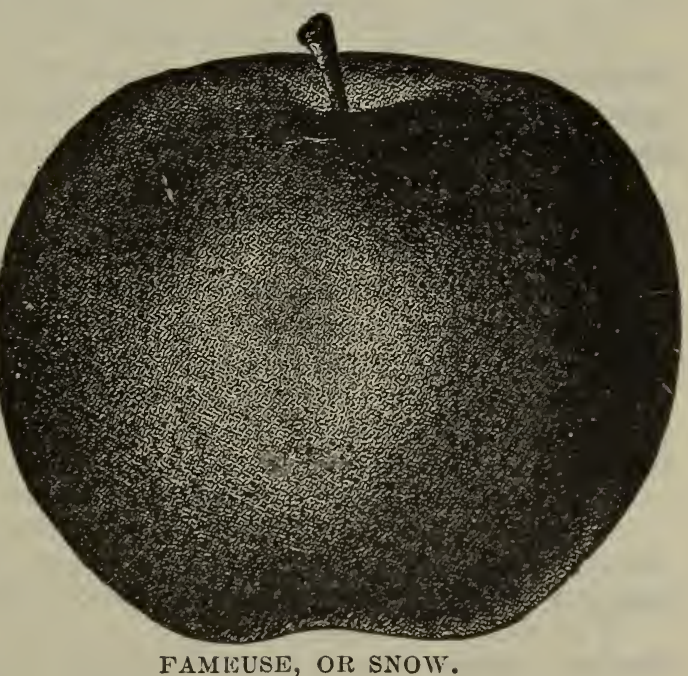

*Hurlburt-Medium; yellow, striped with red; tender, juicy and excellent. Oct. to Dec.

Maiden's Blush-Medium, pale yellow, red che k, fine quality, sub-acid. October.

Rambo-Medium, streaked and splashed with 1 ed, rich, sub-acid. Fall.

* Rolfe-Originated in Maine; good bearer and fine quality; very attractire. Oct. and Nov。

* Red Beitigheimer-A valuable German variety. Fruit very large, skin pale ye?low, covered with crimson; flesh white, firm, sub-acid. A free grower and good bearer. September.

*St. Lawrence-Large, round, striped with red, flesh white, juicy, tender, sub-acid; fine.

Stump-Good size, pale yellow, splashed with red; excellent quality, vigorous and productive.

Western Beauty-Large and handsome; roundish oblate; waxy-yellow shaded with carmino in the sun. Excellent quality. A fine apple. 


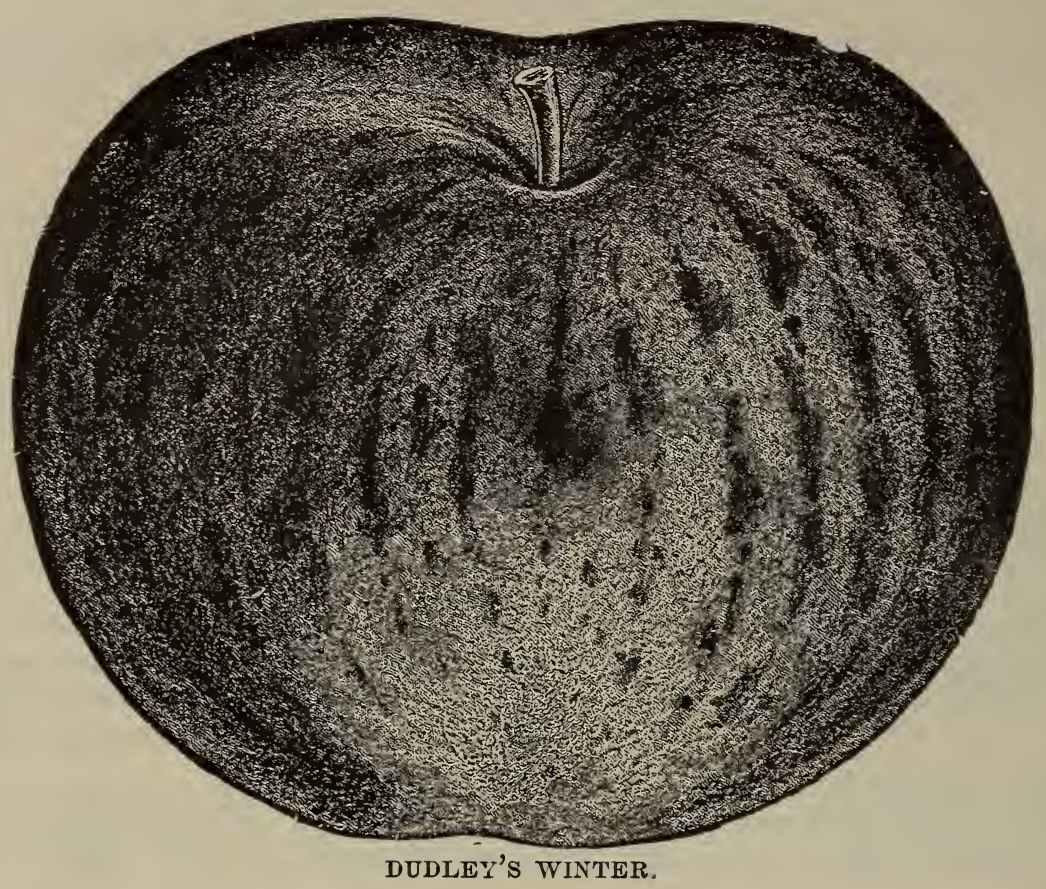

WINTER.

Arkansas-(Mammoth Black Twig)-An Arkansas apple resembling the Wine Sap, only larger; medium size, dark red, flesh yellow, firm and crisp, sub-acid; very productive. Recom. mended as a long keeping rnarket apple for the Middle, Southern and Western States.

Baldw'n-Large, roundish, skin deep red, flesh juicy, crisp, sub-acid, good flavor. Very rigorous and productive. The best all-round winter apple for I Iew England and the Northern States. Keeps splendid. December to March.

*Baxter-Very large, dark red, mild sub-acid; very hardy. November to March.

Bailey Sweet-Large, oblong, deep red, tender, rich, delicious, fine quaiity. Nov. to Feb.

Ben Davis-The great market apple of the West and South, largely planted also in the East. One of the best for profit. Very early bearer and yiclds an immense crop of large sub-acid bright red, fine shaped fruit. The apple is of poor quality, but its attractive color, size and shape, make it sell. It is a splendid keeper and fine for cooking. December to April.

Bellefleur-Large, oblong, yellow, tender, juicy, crisp, sub-acid; fine quality. Dec. to Feb.

"Belle de Boskoop-Large, yellow and red, crisp, tender, juicy; sub-acid. Fall or early winter.

Bismarck-An apple highly prized for its wonderful productiveness and early bearing. Color deep yellow, shader with red, size very large, flesh yellow, tender and juicy; fair quality; excellent for cooking. Sieason early winter. It often fruits at two years old.

*Boiken-A long keeping winter apple, size medium to large, with snow white, fine grained flesh; skin light yellow, shaded with red. The foliage is very thick and healthy, enabling it to produce fine fruit without spraying. An excellent dessert apple. November to June.

- Canada Red-A fine dark red winter apple. Immense yielder; hardy. November to March.

Cooper's Market-Medium, conical, yellow, striped with crimson; flesh white, tender, sub-acid. Vigorous. December to May.

-Dudley's Winter (North Star-Winter Duchess)-Much like Duchess, only it is a winter apple, less tart and better quality. Perfectly hardy in the coldsst climate. Originated in Northern Maine and there considered their finest apple. Valuable for the north.

Fallawater-Large, yellowish green, sub-acid; very productive. November to March.

*Gideon-Very hardy; yellow, medium size; good quality. Fall or early winter.

Golden Russet-Medium, very tender, juicy, rich, sub-acid; high quality. October to January. "Grimes' Golden-Good size, yellow; high quality, hardy. November to March.

Hubbardson Nonsuch-Medium, red striped, tender, juicy; productive; good quality, highly recommended. November to March.

King-An apple of the largest size; deep red, round, flesh yellow, juicy, acid, tender. A light bearer; always in demand and brings the highest prices. A first-class apple for export, as it ship and keeps well. Not prolific enough to be as profitable 9 s some others. November to March. 
Lady-A beautiful little dessert apple, flat, pale yellow with deep red cheek. Juicy, rich and pleasant. November to May.

*Longfield-A very hardy apple; early and abundant bearer. Fruit large, conical, yellow striped with red, sub-acid; in season during the fall and early winter.

*Mann-Large, greenish yellow, tender, juicy, sub-acid; hardy. November to March.

Magog-Red-Large, red, prolific, sub-acid; very hardy. September to March.

*McIntosh Red-A very fine apple of the Fameuse class, hardy; large, dark red; flesh white, very tender, splendid quality. A prolific bearer, but inclined to drop. November to February.

Newtown Pippin-Large, round, greenish yellow. Very high quality, juicy, crisp, tender, rich, sub. acid. December to April.

Northern Spy-Too well known to need description. Crisp, tender, high quality, fine shapeả beautiful coloring. Red, usually striped, sub-acid. Takes 12 to 15 years to come into kearing, but very productive after that. November to March.

Northwestern Greening-Very hardy, greenish yellow, large, mild, sub-acid. Nov. to March.

Peck's Pleasant-Large, pale yellow, fine grained; juicy, high quality, sub-acid. Nov. to Mar

*Pewaukee-Medium, yellow, splashed red, rich, sub-acid. November to March.

Roxbury Russet-Medium, dull green and yellow; flesh white, rich, sub-acid. Nov. to March

R. I. Greening-Large, greenish-yellow; flesh yellow, fine grained, tender, crisp, juicy, sub-acid Fine for cooking. Very productive. November to March.

Rawle's Janet-Yellowish-green striped with red; crisp, juicy and rich. Feb. to June.

*Scott's Winter-A Vermont apple, extremely hardy; medium size, deep red, acid. December.

Seek-no-Further-Large, striped red, fine grained, tender, sub-acid, good; productive. October to February.

Smith's Cider-Medium, yellow, striped red, tender, sub-acid. November to March.

Spitzenburg-(Esopus)-Medium, dull red; flesh yellow, firm, juicy, delicious, sub-acid. November to March.

Stark-Large, red, juicy, sub-acid, mild flavor. November to March.

Stayman's Wine Sap-Similar to Wine Sap except larger, better quality and more productive. December to May.

Sutton Beauty-Resembles Baldwin, but better quality; medium size, yellow, striped with erimson; tender, good, sub-acid; productive and early bearer. November to March.

Talman Sweet-Medium, pale whitish-yellow; flesh white, fine grained; very hardy and productive. The best winter sweet apple for home and market. November to March.

Twenty Ounce-Very large, yellow and red, tender, juicy, crisp, sub-acid; productive. October to January.

Wagener-Medium, yellow, shaded with crimson; very tender, juicy, crisp; early bearer. Mild acid, fine flavor. Very productive and a fine apple. November to February.

"Walbridge-Medium, striped red; crisp, tender, juicy, sub-acid; productive. Jan. to May.

*Wealthy-An American apple that is becoming very popular on account of its hanojame appearance and early fruiting. Hardy and productive. Fruit large size, roundish, skin smooth, splashed with dark red; flesh white, tender, juicy, sub-acid. Nov. to Jan.

Wine Sap-Medium, deep red; firm, crisp, high flavor; popular in Southwest. Dec. to May.

Winter Banana-An excellent new apple of large size, very showy in appearance, roundish, deep yellow with red cheek. In season in November and keeps well till spring. Is a bandsome apple and has a Banana perfume; tender and delicious.

Wolf River-Very large, yellow shaded crimson; acid, juicy. December to February.

York Imperial-Medium, whitish shaded crimson; firm, crisp, juicy, mild, sub-acid. Very popalar in Pennsylvania and the middle South. November to February.

\section{CRAB APPLES.}

Excelsior-Handsome,hardy, red and yellow, fine flavored; ripens early; size of Fameuse. Sept. General Grant-Large, red and yellow, flesh white, fine quality. October.

Hyslop-Large, dark rich red, flesh yellow, sub-acid; productive, hardy and popular. Oct.

Lady Elgin-Fruit beautiful, resembling Lady. Flesh yellow, juicy, mild sub-acid. Nov. to Deo.

Martha-One of the largest and finest crabs; red and yellow. Fine for sauce. October.

Transcendent-Large, yellow with rich crimson cheek. An improved Siberian crab. September. Whitney-Large, greenish striped with carmine; flesh firm, juicy and rich. Season last of Aug Vellow Siberian-Large, pale yellow; mild acid; a free grower. September and October. 


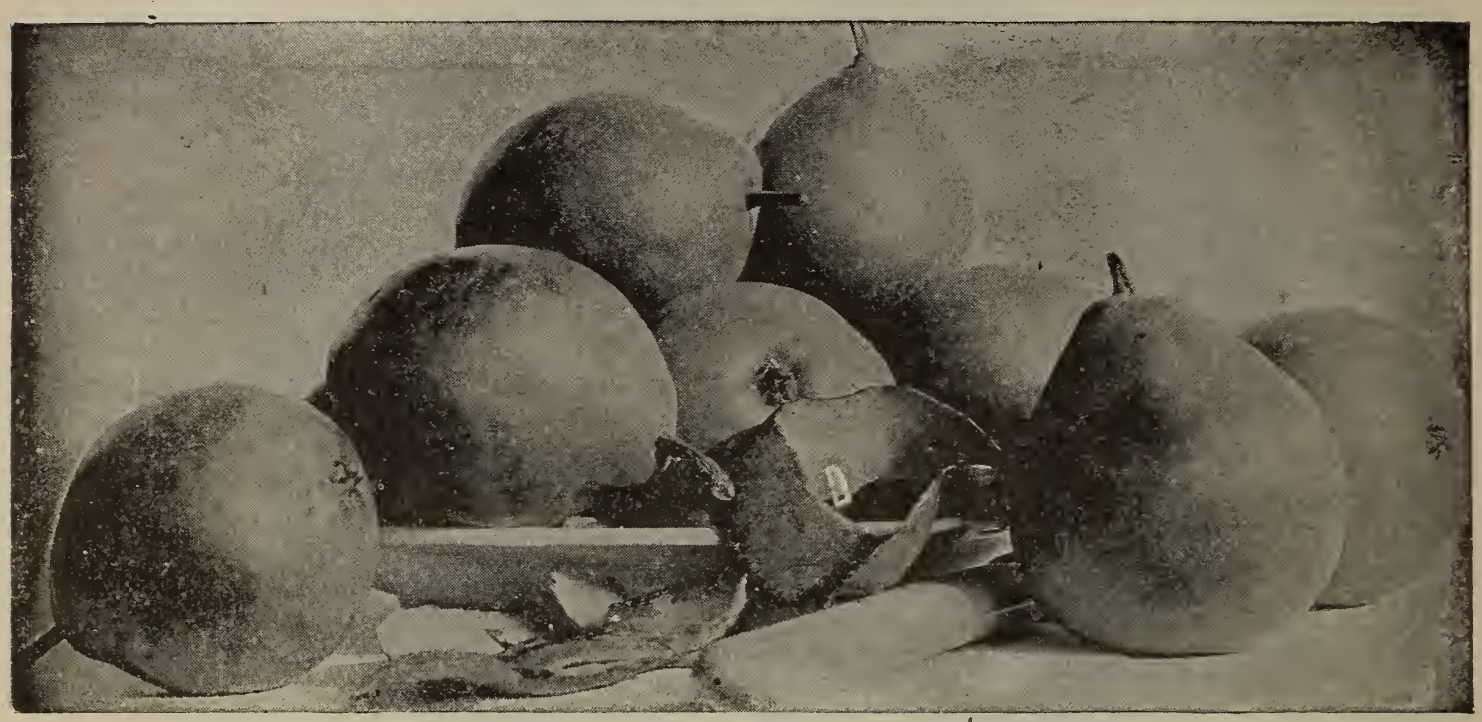

\section{SUMMER PEARS.}

Bartlett-Large size, rich, melting, delicious; everywhere successful. The best early market pear. Requires thinning to get the largest size fruit. Blossom sterile, requiring other varieties planted near by to insure fertilization. September.

Clapp's Favorite-Tery large and showy, golden yellow with red cheek; rery productive. Ripens a week before Bartlett. Rots at the core unless picked 10 days before ripe. August.

Koonce-Fruit large, yellow with crimson cheek; quality good, spicy, juicy, sweet; very early. Souvenir du Congress-Very large, bright yellow, very showy, juicy; a fine pear. Aug. and Sept. Tyson-Small, melting, juicy; fine eating. August.

Wilder-Medium size, yellow with carmine shading; tine grained, tender, sub-acid. August.

Other Good Summer Pears-Beurre Giffard, Doyenne de Ete, Osband's Summer.

\section{AUTUMN PEARS.}

Bartlett-Seckel-(Columbia)-Combining good qualities of both; handsome and good. Tree vigorons add hardy. September and October.

Belle Lucrative-Large, melting, rich. September.

Bessimianka-A Russian pear of good quality. Medium size, green with some russet. Oct.

Beurre Clairgeau-Very large and attractive; color rich yellow and red; flesh coarse. Keeps well; excellent for canning and market; very productive. September.

Duchess de Angouleme-Very large, greenish yellow, tender, melting, buttery and juicy; does best as a dwarf. October.

Flemish Beauty_Large, sweet, melting; very productive, but liable to scab; very hardy. Sept.

Howell-One of the finest fall pears; large, yellow, rich. Splendid quality. September.

Idaho-Largest size, melting, juicy; tree very hardy and productive; late. October.

Kieffer-Very large, deep yellow with russet dots; juicy, sweet, coarse; immensely productive; very early bearer. Fruit must be thinned to get the largest size. Fine for canning. Said to be blight-proof. October and November.

Louise Bonne-Good size, greenish yellow with red cheek; good. Sept. and Oct.

Seckel-Small, finest flavor; excellent for pickling and dessert; very productive. September.

Sheldon-Medium size, round, russet and red; melting, rich, very juicy, delicious. Fine for dessert; very productive; keeps well. October.

Vermont Beauty-Medium size, yellow shaded with carmine; flesh melting; good quality; very hardy. October.

Worden-Seckel-A seedling of the Seckel, only larger. Fully equal to it in quality, and more juicy, equally luscious and with the same rich and inviting aroma, while in size, color and form it is decidedly superior. Color golden yellow with bright red side. Skin smooth and waxy with russet dots. Season October to December.

Other Autumn Pears-Beurre Superfine, Beurre Hardy, Beurre Bosc, Buffum, Frederick Clapp. 


\section{WINTER PEARS.}

Beurre de Anjou-A grand pear; large, handsome, buttery, melting, rich; yellow when ripe. The finest winter pear grown. Requires to hang late and is liable to fall on standard trees. Does best as a dwarf. October and January.

Easter Beurre-Large, yellow, with dull red cheek; rich and melting. All winter.

Henry-Large, good quality, fine keeper. One of the best late winter pears. Dec. to Feb.

Josephine de Malines-Medium to large, straw color, delicious; very late. Requires thinning. January to March.

Lawrence-Medium size, golden yellow, melting, very rich. The finest early winter pear. November and December.

Lincoln Coreless-Usually no core or seeds; very large. Flesh juicy and aromatic. December to March.

Mt. Vernon-Medium, light russet and red, juicy, aromatic. November and December.

President Drouard-Large, melting, juicy, rich; hardy and vigorous. February to March.

Winter Nelis-Medium size, greenish yellow, spotted with russet. Melting and of finest quality; bears heavy crops.

Profit-It is claimed that there is more money in dwarf pears at $\$ 1.00$ per barrel than in apples at $\$ 2.00$.

Cultivation-Plant aeep, with juncture of bud and stock fully three inches below the surface. Every year the new growth must be kept cut back one-half to one-third, and keep the top of tree open, and the tree dwarf. Pinching top buds in the summer will produce fruit buds. Let them branch close to the ground, keep clean until well established.

Following are the varieties best adapted for growing as dwarfs:

Belle Lucrative-Mid-autumn.

Beurre de Anjou-Early winter.

Clairgeau-Late fall.

Clapp's Favorite-Very early.

Doyenne d'Ete-Summer.

Duchess-Late fall, fine.

Easter Beurre-Late winter.

Howell-Early fall.

Idaho-Late fall.

Louise Bonne-Early fall.

Lawrence-Early winter.

Mount Vernon-Early winter.

Osband's Summer-Mid-summer.

Seckel-For table and pickling.

Tyson-Early summer.

Vermont Beauty-Tery hardy.

Vicar of Winkfield-Winter.

Wilder Early-Early summer.

\section{DWARF PEARS.}

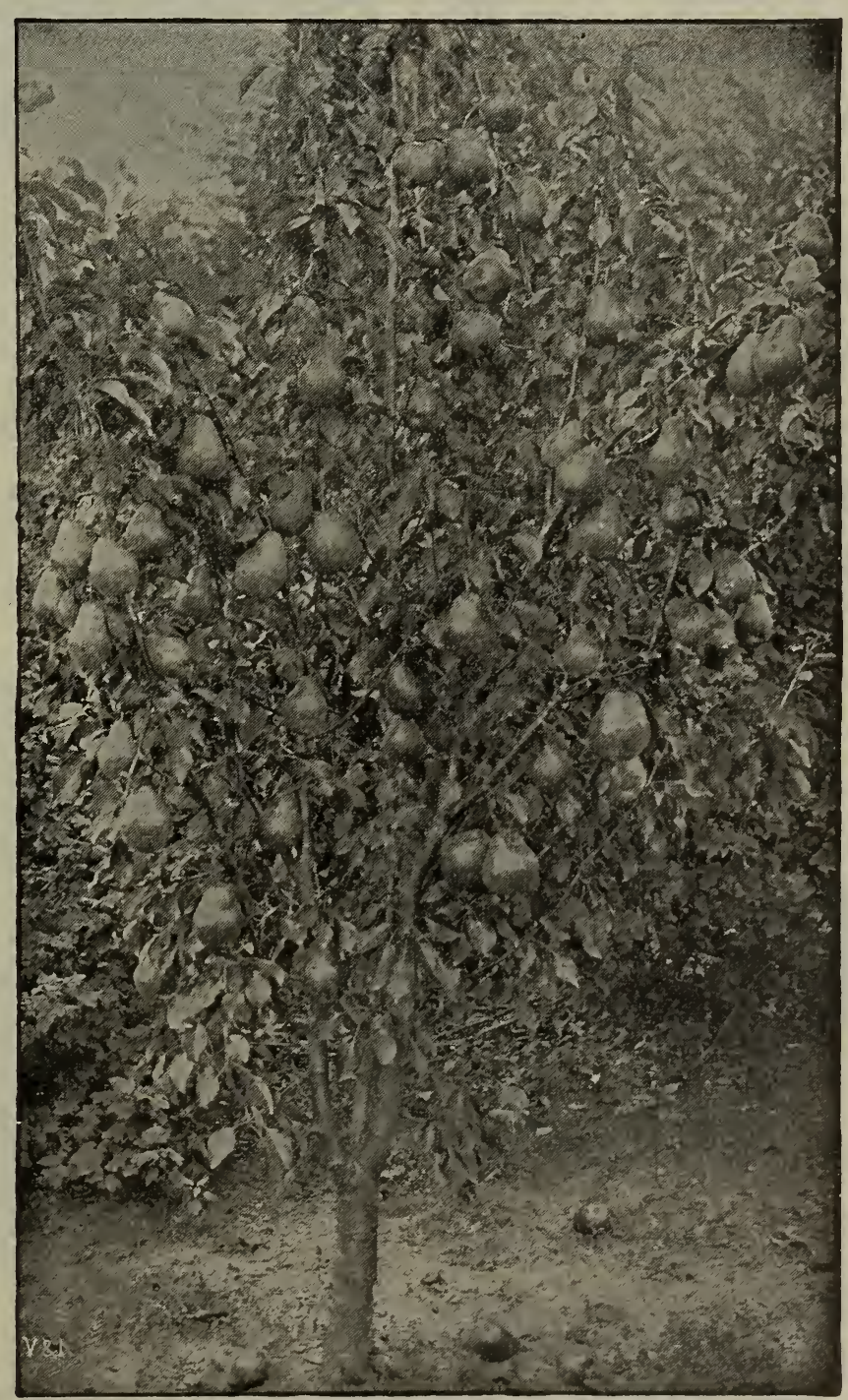

A YOUYG DWAKF DUCHESS PEAR TREE. 


\section{Cherries-Hearts and Bigarreaus. (Sweet.)}

Allen-Large, black, meaty, firm and excellent. Healthy and productive. July.

Black Tartarian-Fruit very large, heart shape. Dark purple, tender, rich, good, very prolific. Tree upright, vigorous and healthy. The best early black cherry. June and July.

Dikeman-Large, heart-shaped, black. Flesh firm, rich, sweet and good. Remarkable for its long keeping qualities, hence valuable for shipping. A very fine variety.

Governor Wood-Large, light red, tender, delicious. Very early and productive. Hangs well. June.

Ida-Originated in Pennsylvania. Ripens with May Duke and equally as hardy. Quality excellent.

Mercer-Very large, heart shape, dark red, fine flavor, early and prolific. A sure cropper. Very hardy and

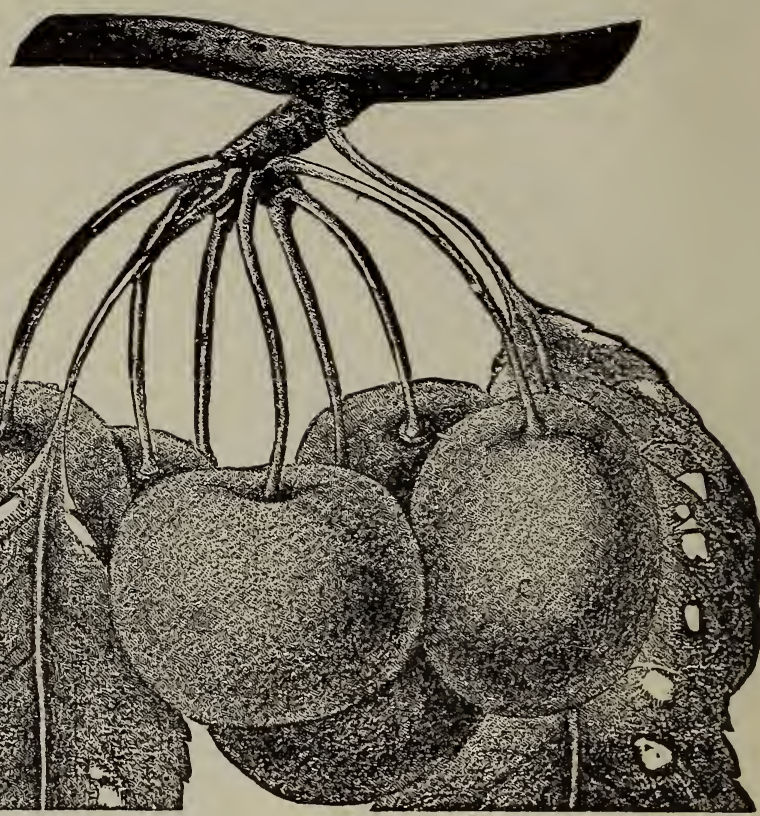

WINDSOR. healthy, strong grower. Said to be very free from worms. June.

Napoleon-The largest size, yellow with red cheek. Very firm, juicy and sweet. Vigorous, upright tree. Very valuable for market and shipping; enormously productive. July.

Schmidt's Bigarreau-A fine, rich, deep black cherry; very large. Flesh firm, dark, tender, juicy and rich. Tree thrifty, upright grower, fine for market. Very late.

Windsor-Very large, liver colored, finest quality; very vigorous and productive. Firm and excellent for shipping. Very late.

Yellow Spanish-Large, early, yellow with bright red cheek. Heart shape; firm, juicy, rich, high flavored; makes a large tree; much grown for market. End of June.

Other Sweet Cherries-Blick Eagle, Black Heart, Black Russian, Coe's Transparent, Downer's Late Red, Early Purple. Elton, Knight's Early, Lewelling, Rockport Bigarreau.

\section{CHERRIES.-Dukes and Morellos. (Sour.)}

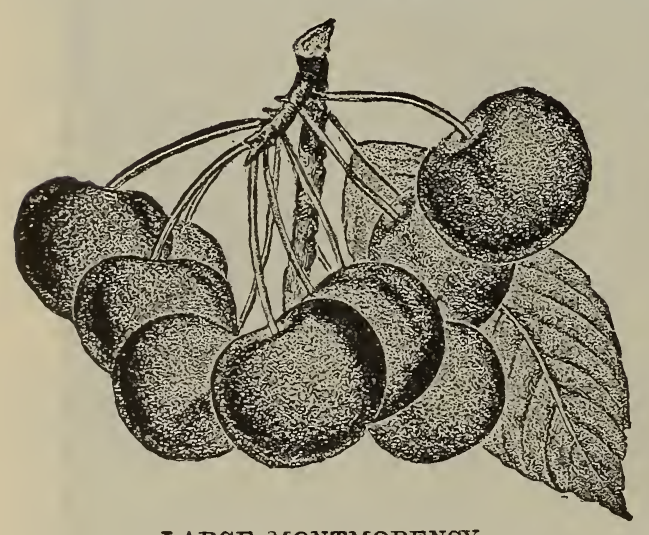

LARGE MONTMORENCY.

Dyehouse-Medium size, like Early Richmond, but said to ripen a week earlier. June.

Early Richmond-Medium size, bright red,acid, very hardy and productive. Fruits very young. For cooking and market one of the best. June.

English Morello-Medium size, dark red, acid, late; dwarf. Very hardy; early bearer. July.

Large Montmorency-Fruit large, bright red, fine flavor; very hardy and immense bearer. Season a little later than Early Richmond.

Lutovka-Vigorous grower; fruit large, firm and good. Clings to the long stems. Late.

May Duke-Large, heart shape, red, tender, subacid, very hardy. Early. Middle of June.

Ostheime-Large, tender, juicy, almost sweet, very good, extremely hardy. July.

Olivet-Very large, shining deep red, tender, rich, mild acid, very showy; an abundant bearer; one of the finest sour cherries. June and July.

Rocky Mountain Cherry-This is a shrub, which originally grew wild in the mountains of Colorado. The fruit is jet black when ripe, and in sizi averages about with English Morello.

ather Sour Cherries-Emp. Eugenie, L. Duke, I. Phillippe, Licb. R. Hortense, Vladimir, Wragg. 


\section{Plums.-European.}

Archduke-Large, black and prolific. Valuable for home or market. Oct.

Beauty of Naples-Medium size, greenish yellow, very sweet, excellent flavor, thin skinned, hardy. Fine for dessert. September.

Coe's Golden Drop-Large, pale yellow, flesh firm, rich, juicy, very hardy, fine. September.

Damson-Smail, oral, purple, covered with blue bloom; flesh melting and juicy, rather tart. Excellent for preserving. September,

Fellemburg (Italian Prune)-Very large, rich dark purple, flesh juicy and good, rather coarse, freestone, tree spreading; productive. September.

German Prune-Medium size, dark blue, juicy, rich. Tree upright, vigorous and productive. Sept.

Grand Duke-Very large, deep purple, fine flavor, entirely free from rot. Last of September.

Green Gage-Small, delicious, very prolific, fine for table use. August.

Monarch-Large, dark purple, freestone, delicious quality. Tree strong, upright and productive. Does not crack with rain. Season last of Sept.

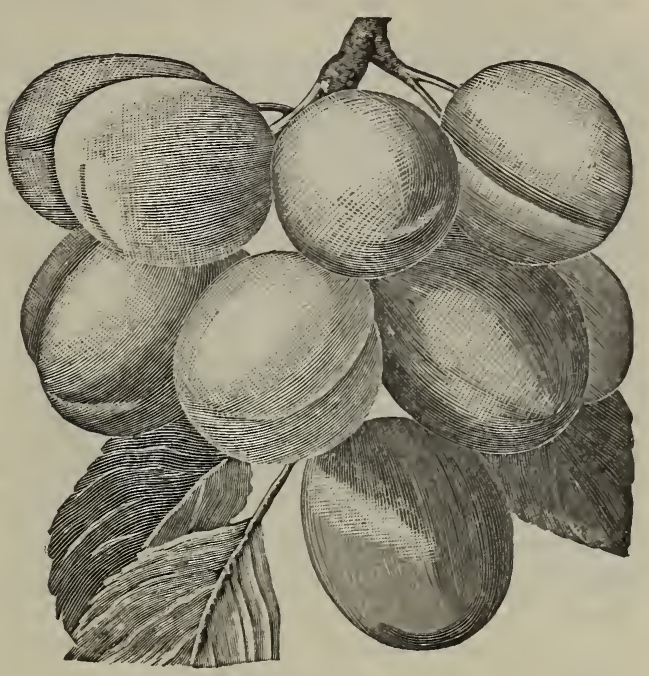

LOMBARD.

Orleans-Very large, reddish-purple; flesh yellow, firm and juicy. Very fine. Aug. and Sept.

Pond's Seedling-Very large, egg shape, brilliant red, flesh juicy, sugary, rich. Septemỉer.

Reine Claude-Large, yellowish green, juicy, melting, sugary, rich flavor. September.

Shropshire Damson-Larger and better than common Damson. October.

Simoni-A Chinese plum of large size, flattened, and of dull brick-red color; flesh yellow with peculiar aromatic flavor. Makes a handsome ornamental tree. October.

Yellow Egg-Very large, golden yellow, fine quality; very productive. August.

\section{PLUMS.-American.}

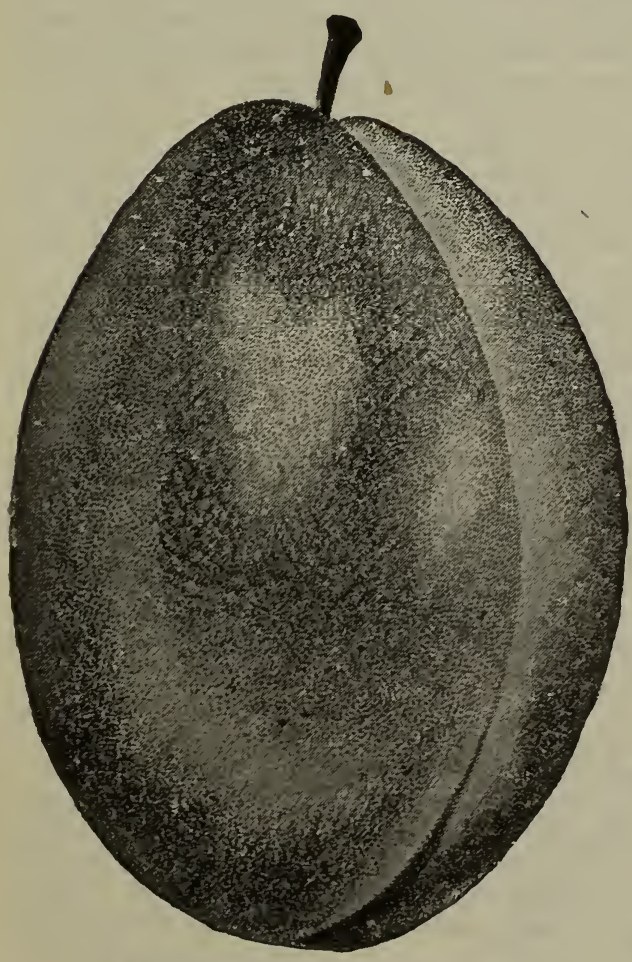

GIANT PRUNE-ACTUAL SIZE.

Aitkin-Very large, oblong, red, good quality. Medium early. Valuable for kitchen or market.

Bradshaw-Very large, purple, juicy, excellent quality. Tree erect and vigorous, productive. Aug.

De Soto-Very hardy, productive; medium size, bright red; good quality. September.

Giant Prune-Very large, measuring $2 \frac{1}{2}$ inches long and 2 inches in diameter, reddish purple, flesh yellow, sweet and firm, rich, delicious, freestone; an excellent shipper. Tree fairly vigor. rous and productive. September.

Guii-Very large, deep purple, flesh yellowish, sweet; early and prolific bearer; hardy. Sept.

Hawkeye-Large, light red, superior quality, firm; tree hardy, thrifty. September.

Hale-A large, handsome plum, bright orange, mottled with cherry-red; flesh yellow, quality good. Originated in California. Sept.

Imperial Gage-Medium size, yellow, juicy, rich, delicious, productive, strong grower. Aug.

Jefferson-Large yellow with red cheek, very rich luscious, high flavored. August.

Klondyke-Large, yellow, nearly covered with red when fully ripe. Hand some, good quality and productive.

Lombard-Medium, violet red, juicy, pleasant and good. Immensely productive, hardy. Aug.

Marianna-Similar to Wild Goose, but earlier. Tree hardy and abundant. 
Milton-Large, round, dark red, thin skin; flesh firm and good; prolific. Early.

Moore's Arctic-Medium, dark purple, thin skin, fine flavor; a great bearer, extremely hardy. September.

Niagara-Identical with Bradshaw or nearly so.

Quackenboss-Large, deep purple; flesh greenish yellow, juicy and sweet. September.

Shipper's Pride-Very large, dark purple, juicy, sweet, fine quality. Hardy and productive. September.

Spaulding-Large, yellowish-green; flesh firm and rich; parts readily from stone. August.

Stanton-Medium, purple, excellent quality, very productive. September.

Stoddard-One of the largest of native plums. Color light red and very handsome. Excellent quality. Medium season.

Tatge-Large, round, dark violet red, fine quality. Hardy and productive. September.

Tennant Prune-Large, dark purple, with blue bloom. Rich, sugary and delicious. Hardy and productive. Valuable for drying.

Tragedy Prune-Large, oblong, reddish-purple, excellent quality. Early.

Washington-Very large, yellow marker with red, flesh firm, juicy; productive. August.

Weaver-Fruit medium, red; fair quality, very prolific, hardy. September.

Wild Goose-Fruit medium, bright red, flesh juicy and sweet. August.

Wolf-Vigorous, hardy and becoming very popular; freestone. Large, roundish-oblong, red; excellent quality. Valuable for market. Season medium.

Wyant-Medium; roundish-oblong; yellow and red; flesh rich and excellent; hardy. July.

\section{PLUMS-Japanese and Hybrids.}

Abundance-Fruit large, showy and beautiful. Color amber, turning to a rich bright cherry red, highly perfumed. Flesh light yellow, juicy, tender and delicious, freestone. The tree is a strong upright grower, immensely productive. Season early.

America-A cross between Robinson and Botan, combining quality and size of the Japanese with hardiness of our native. Fruit large, and is not surpassed in beauty by any, being a glossy coral-red color. Flesh light yellow, moderately firm and of excellent quality. Ripens very early; a splendid keeper. Tree vigorous, hardy and productive. One of the best.

Apple-Tree a fine, strong, somewhat spreading grower. Fruit very large, striped and mottled until nearly ripe, when it turns to a deep reddish-purple. Highly flavored, sub-acid, rather firm, of pinkish color, nearly freestone. Ripens after Burbank and keeps for a month.

Bartlett-In flavor and fragrance exactly like the Bartlett pear. Light salmon-colored flesh, rather firm, yetjuicy; semi-free. Bears the second year. Tree upright. Ripens before Burbank.

Burbank-Flesh yellow, firm, tender and very juicy, rich, sweet and aromatic. Blooms late, very productive. Tree spreading and hardy. One of the best. Medium.

Chabot or Yellow Japan-Medium to large, orange yellow overlaid with light cherry red; flesh yellow, sweet and excellent. Tree a strong, upright grower and very productive. Medium.

Chalco-A cross between Simoni and Burbank. Flesh sweet, firm, fragrant. Fruit is almost stemless and completely surrounds the older branches. A superior shipping plum, as it ripens well when picked green and keeps nearly a month. Early.

Climax-Tree extremely vigorous, upright, with strong branches and very large leaves. Productive as Burbank, about as large, two or three weeks earlier and more richly colored.

Kelsey-Large size, greenish-yellow, lightly overspread with red. Fine quality. Not hardy.

October Purple-Originated by Burbank, who regards it as one of the best introduced. Fruits on the old wood and frequently measures seven inches in circumference. Flesh yellow; superb quality; stone small. Tree a strong, erect grower, forming a shapely head. Medium.

Ogon-Large, round, light yellow with white bloom; flesh firm, sweet, rich and dry. Early.

Red June-Fruit medium to large, deep vermilion red, very showy, flesh light lemon yellow, slightly sub-acid; half cling, pit small. Tree hardy, upright and productive. Very early.

Satsuma-Large, nearly round, purplish-red; flesh firm, juicy, dark red, pit small. Medium.

Shiro-Tree a strong grower; wood hard and wiry. Fruit, which is produced in great profusion, is large, clear light yellow, and so transparent that the pit can be seen through the flesh, which is firm and juicy; rich, sub-acid; cling-stone. Keeps for a month. Medium.

Sultan-Said by Luther Burbank. the originator, to be one of the most attractive of plums. It is a cross between Wickson and Satsuma. Its huge size, deep purplish-crimson color, render it most valuable for market. Flesh firm, fragrant, sweet, dark crimson. Early.

Wickson-Large, color carmine with a heavy white bloom; stone small; flesh fine, firm, sugary and delicious. Picked green, will ripen and color perfectly and keep two weeks or more after ripening, making it an excellent market plum. Tree upright grower and productive.

Willard-Fruit medium size, bright red, firm, freestone. Handsome, keeps a long time. Poor quality, but being very early brings a high price. Tree hardy, a strong grower and productive. Earliest. 


\section{Peaches.-General List.}

Alexander-Medium, white, covered with red; juicy and sweet; semi-cling. July.

Bokara-Large, yellow with red cheek; good quality and a fine shipper. August.

Beer's Smock-An improved Smock.

Carman-Large, oblong, pale yellow with deep blush; flesh tender, juicy and fine flavor; very hardy and a heavy bearer. August.

Chair's Choice-Large, deep yellow, red cheek; firm; a few days earlier than Smock.

Champion-A white freestone, ripening about September 1st. Delicious, sweet, rich and juicy, skin creamy white with red cheek, strikingly handsome. It is hardy, productive, early, largest size and highest flavor.

Brawford's Early-Very large, yellow, rich, sweet, luscious; free. September.

Crawford's Late-Very hardy, large, yellow, rich, sweet; free. September.

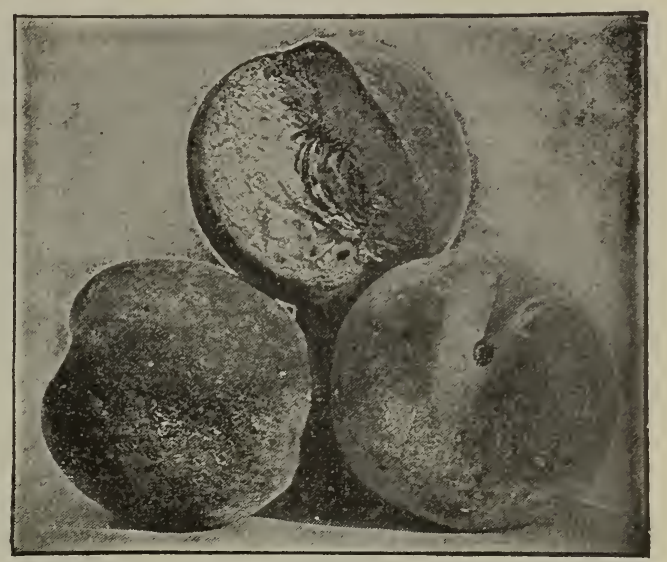

TRIUMPH PEACH.

Crosby-A beautiful yellow freestone peach with very sinall pit. "ixcellent flavor, large size, color orange-yellow, with carmine on the sunny side. Fery beautiful; tree willowy growth, like Wager; rather dwarf; ripens between early and late Crawford.

Elberta-Among peaches Elberta takes the lead for beauty, size and quality. It is one of the hardiest, as large or larger than Crawford's Early, and fully its equal in beauty and flavor. One of the finest yellow freestone peaches. Fruit yellow with red cheek; flesh yellow, juicy, and of good quality; ripens slightly later than Early Crawford.

Fitzgerald-A native seedling, as large or larger than Crawford; freestone, very best quality. A heavy bearer, fruiting very young, almost invariably the second year after planting. Very hardy. Ripens just after Crawford's Early.

Globe--Extra large, yellow, flesh firm, juicy, excellent. Freestone.

Greensboro-Larger and earlier than Alexander, and is nearly freestone. It is colored beautifully with crimson and has a yellowish cast; the flesh is white and of good flavor. The peach is large, many specimens measuring 8 to 9 inches in circumference. Productive.

Kalamazo0-A leading Michigan market sort; large, yellow, fine quality. Extra productive and profitable.

Lemon Free-Very large, oblong, yellow, fine quality and immensely productive. Late.

Mountain Rose-Very hardy, large, red, flesh white, juicy, rich and excellent; free. Auguit.

Old Mixon Freestone-Large size, flesh white, tender, juicy ; free. September.

Salway-Very large, yellow, firm, juicy, melting, rich; very late, ripening in October; hee.

Smock-Large, light yellow, flesh yellow, juicy, rich; free. October

Sneed-Medium, creamy white with light blush; good quality; very early. July.

Triumph-It ripens with Alexander, blooms late, has large flowers; a sure and abundant bearer. The fruit is of large size, with a very small pit, and is indeed beautiful. Surface is yellow, nearly covered with red, and dark crimson in the sun; flesh bright yellow, free when fully ripe and of excellent flavor.

Wheatland-Extra large size, handsome golden color; ripens between Early and Late Craw. ford; excellent quality; very firm and bears shipment well; freestone.

Wonderful-Large, rich golden yellow, flesh yellow, rich, bighly flavored, free. September.

Yellow Rareripe-One of the earliest; medium size, skin yellow, a fine peach; free. August.

Additional Varieties of Peaches.

Amsden, white, e.c.

e for early ; $m$ for medium; 1 for late ; for free ; $c$ for cling.

Garfield, vellow, m. f.

Barnard's Early, yellow, m. f. Hale's Early, e. f.

Conkling, m. f.

Early Canada, white, e. c.

Early Louise, white, e. f.

Early Rivers, white, e. f.

Early York, white, e. f.

Foster, yellow, m. f.
Hill's Chili, yellow, m. f.

Honest John, yellow, f.

Jacques' Rareripe, m. f.

Lord Palmerston, white, l. f.

Morris White, white, m. $\mathrm{f}$.

Red C. Melocoton, yellow, l. f.
Salway, yellow, l. f.

Schumaker, yellow, m. f.

Steadley, white, l. f.

Stevens' Rareripe, white, 1. 1.

Stump the World, white, l. f.

Susquehanna, yellow, m. f.

Wager, yellow. \$n. f. 


\section{APRICOTS.}

Apricots are a rich, delicious fruit, coming between cherries and peaches, very much like the peach in outward appearance, but like the plum in quality and texture. One of the finest fruits for drying, and they fill a season when there are no other large fruits.

Acme-A new and fine variety. Tree stout, healthy and hards with handsome fcliage. Fruit large and sweet; rich yellow with red cheek. July.

Breda-Small, deep orange marked with red; juicy, rich and vinous. Last of July.

Early Golden-Small, pale orange, juicy and sweet; hardy, productive. July.

Harris-Rich golden yellow; large size, very fine quality; hardy, early bearer and prolific.

Montgamet-Medium size, early; juicy and excellent; hardy. July.

Moorpark-Large, orange and red, firm, juicy, rich flavor; very productive. August.

Royal-Large, yellow, juicy, rich and delicious. August.

Russian-Small, yellow; very hardy and productive. Poor quality. July.

\section{NECTARINES.}

Boston-Iarge, bright yellow with red cheek; flesh sweet and tender. Sept.

Downton-Large, greenish white with dark red cheek; rich and high flavored. August.

Early Violet-Yellowish green with purple cheek; melting and rich. Last of August.

\section{Quinces.}

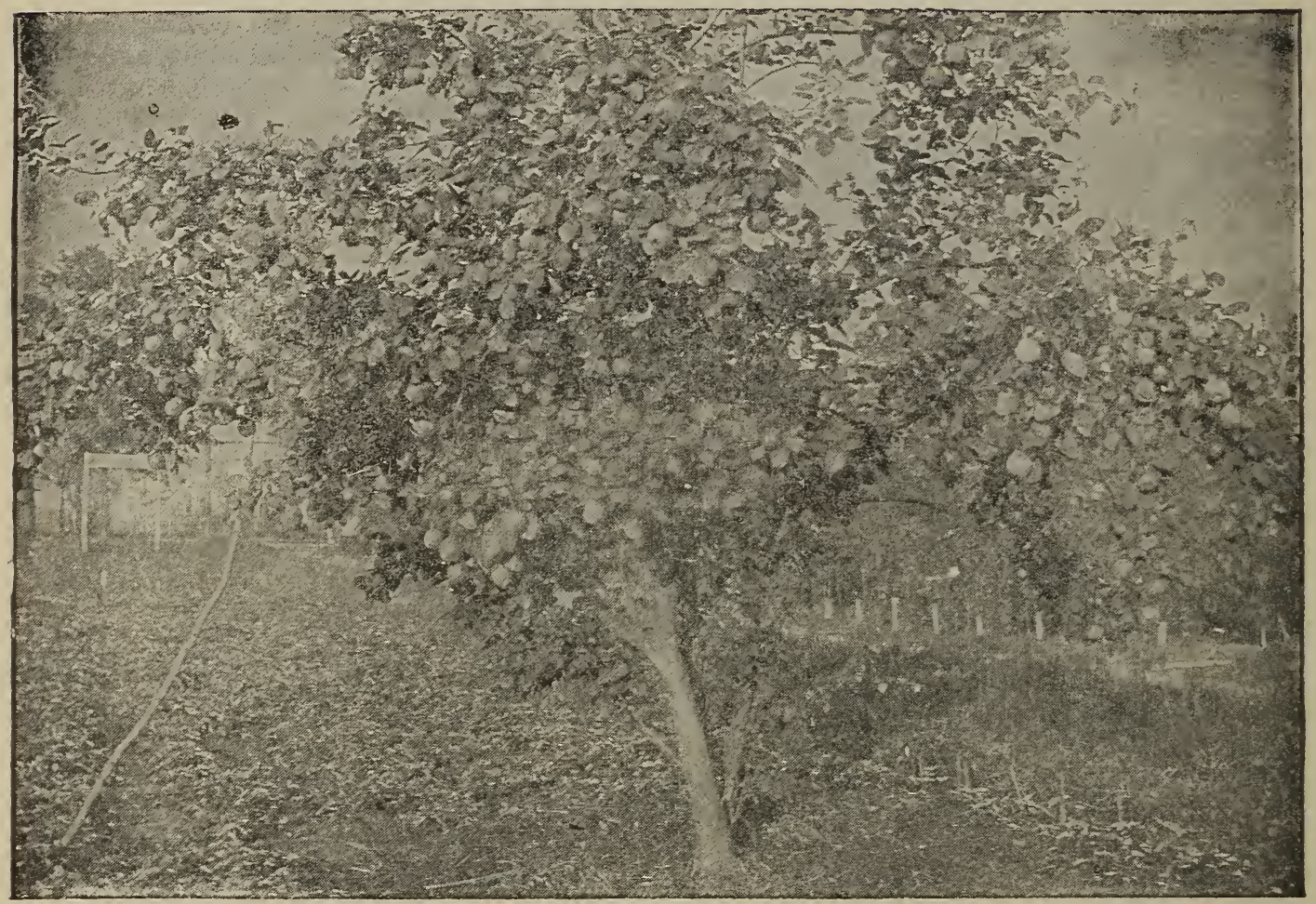

BOURGEAT QUINCE.

Bourgeat-A French variety. Very productive, healthy and thrifty. It grows in tree form, like Pears or Plums. It has almost perfect foliage, leaves green and fresh unto the end of the season. The fruit is very large, smooth, golden yellow, of the best quality, tender; ripens just after the Orange, and will keep past midwinter in perfect condition.

Champion-Very large size, rich, golden yellow when ripe; a great bearer; very late. Nov.

Meech's Prolific-Fruit bright yellow; flesh very fragrant and tender, unsurpassed. October.

Orange-Very large, bright golden yellow, fine quality; flesh firm, cooks tender. October.

Rea's Mammoth-Very large, bright golden yellow. Ripens very early; very prolific. October. 


\section{Nut Trees.}

\section{ALMONDS.}

Mard Shell-A fine, hardy variety, with a large, plump kernel.

Paper Shell-Not as hardy as above, kernels sweet and rich.

\section{CHESTNUTS.}

American Sweet. - Nuts sweet, delicate flavor.

\section{JAPANESE CHESTNUTS}

Alpha-The earliest known Chestnut; bears at 3 years old and very productive. Nuts large, four inches arouna and two to three to a burr. Ripens September 10th to 12th without frost.

Early Reliance-Tree dwarf and very productive. Nuts large, measuring four inches in circumference, and running three to five nuts to the burr. Ripens September 18 th to 20 th.

Giant-Nuts of immense size, very sweet. Bears young.

Mammoth-Nuts are of a superior flavor and sweetness. It comes to bearing at three to four years of age. Very productive.

\section{SPANISH CHESTNUTS.}

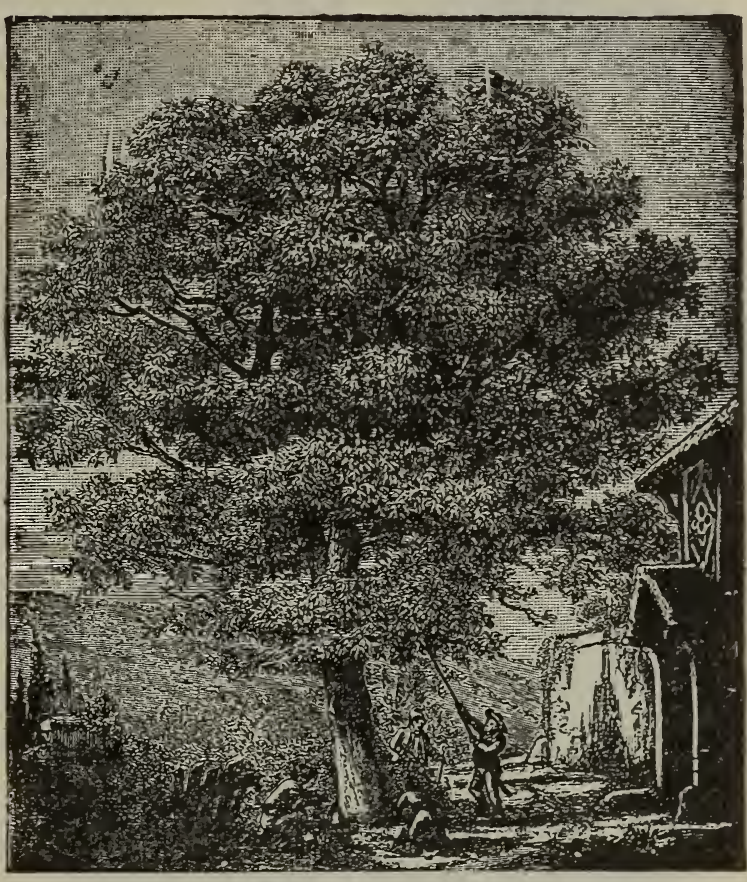

BLACK WALNUT.

Spanish-A handsome, round-headed tree, producing very large nuts.

Numbo-Very hardy and productive, ripens early, usually before frost.

Paragon-Nuts large, three or more in a burr; early and abundant bearer.

Ridgely-A strong grower; rich, sweet nuts; very prolific.

\section{FILBERTS.}

American-Smaller and with thicker shell than the English; fine flavor, hardy and productiva

Kentish Cob-One of the largest filberts; oblong, excellent quality.

Cosford, Thin Shell-Very thin shell; sweet kernel.

English-The sort usually sold at the fruit stands.

\section{HICKORY.}

Shellbark-A peculiar, rich, native nut, in flavor excelled by none.

\section{PECAN.}

Paper Shell-Sweet, oblong, smooth nuts of good quality, tender.

\section{WALNUTS.}

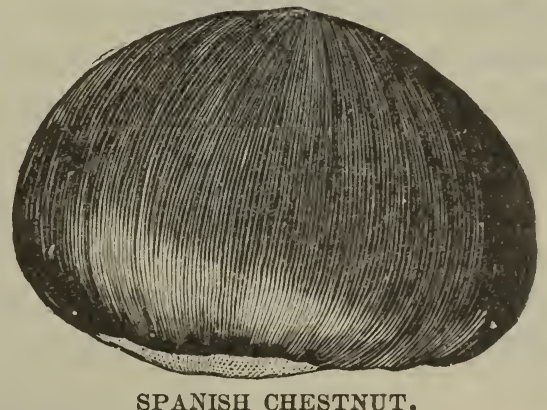

Butternut-A native tree, valuable for timber, and bearing an oblong, thick-shelled nut of delicious flavor.

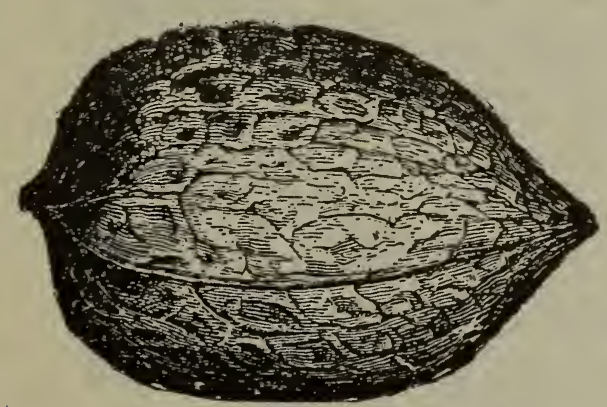

JAPANESE WALNOT.

Walnut, Black-A native tree of large size and majestic form. The most valuable of all trees for its timber. Tree a rapid grower, producing a large, round nut of excellent quality.

Walnut, English-It produces immense crops of thinshelled delicious nuts. Fruit in green state is highly esteemed for pickling. Not entirely hardy.

Walnut, Japan (Sieboldi)-Perfectly hardy, rapid growing, handsome form, immense fern-like leaves, making one of the finest ornamental trees; bears young and abundantlv. Nuts produced in cluo ters and resemble butternuts in shape and qual ity, but somewhat smaller and with thinner and moother shell. Worthy of extencive plantine 


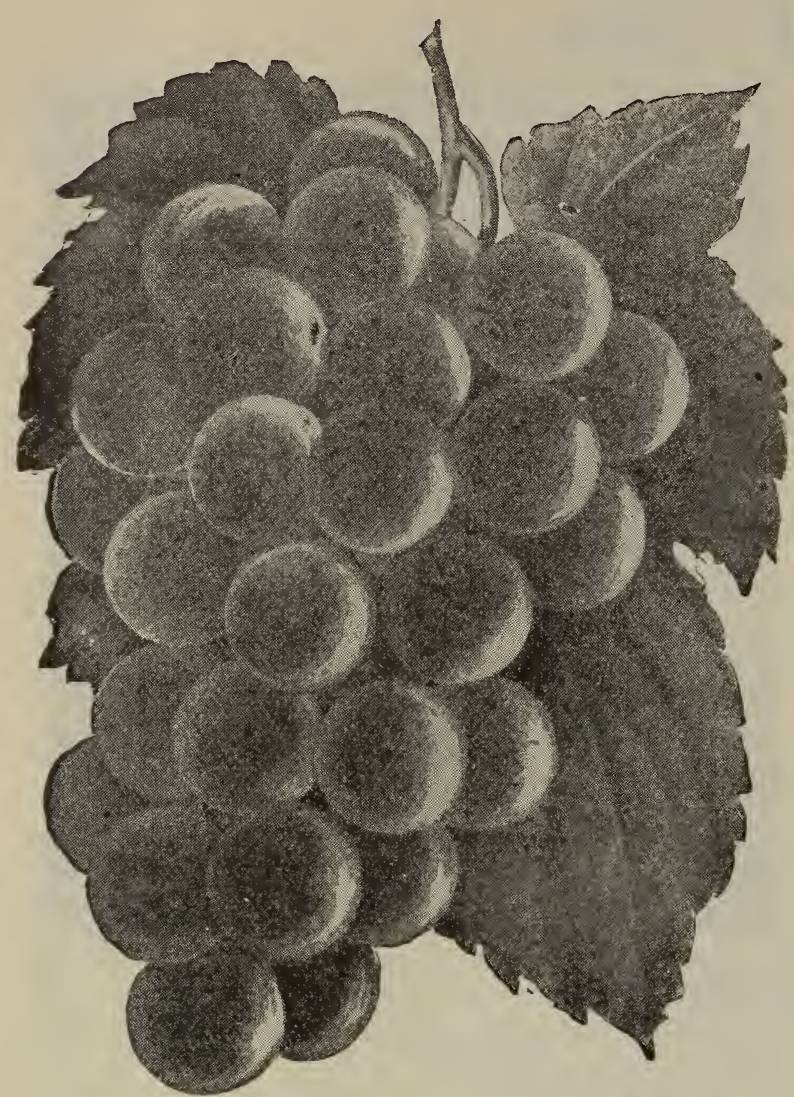

\section{Introduction.}

The Grape is the most healthful of all fruits, and the most highly esteemed for its many uses. Itcan be grown by everyone who has a garden, a yard, or a wall. It can be confined to a stake, bound to a trellis, trained over an arbor, or extended until it covers a large tree or building, and still it yields its graceful bunches of luscious, blooming fruit. Capable of most extraordinary results under wise management, it is prone also to give the greatest disappointment under bad culture or neglect. Other fruits may be had from plants that know no care; but grapes are to be had only through attention and forethought.

Campbell's Early-A new Black Grape said to be superior to Concord in many respects, ripening about with Moore's Early. Cluster and berries very large and handsome. Skin thin. Flesh firm, tender, separating easily from the seeds, Flavor rich, sweet, slightly vinous and without acidity from the skin to the center. A very strong vigorous vine. Thick, healthy foliage. Its early ripen. ing, keeping and shipping qualitie make it a very valuable market grape.

Alice-Without doubt the best long keeping grape ever offered. It is a light red grape; clustere medium size. Perfectly hardy, strong grower. Very free from mildew or other disease.

Brighton (Red)-Highest quality, melting, delicious, large clusters, hardy, almost seedless.

Concord-The old reliable; juicy and sweet, hardy, healthy and productive.

Delaware-A delicious little red table grape; juicy, sweet, hardy and productive.

Diamond-A white grape of high quality; melting and delicious; large cluster, hardy.

Green Mountain-This extra early grape was found growing in the Green Mountains of Vermont at an altitude of 1,400 feet, where it ripened its fruit perfectly. Color greenish-white, skin thin, pulp exceedingly tender and sweet, containing but one or two seeds. The first white grape to ripen. Quality superb.

Moore's Early (Black)-Very early, large berry, extremely hardy, vigorous.

Niagara(White)-A great yielder and of fine flavor; ripens early, clusters very solid, large vines

\section{OTHER STANDARD VARIETIES OF MERIT.}

Agawam, No. I5-Dark red, large.

Amber Queen-Red, fine, ripens early.

Barry-Large, black, much like Black Hamburg.

Catawba-Red, medium, late.

Champion-Black, earliest.

Colerain--Medium, ligh green, ripens early and hangs well, skin thin. tender, juicy an I sweet.

Duchess-White, delicious, ripens with Coucord.

Baton-Black, the largest, very fine.

Farly Ohio-Black, very early, productive.

Early Victor-Black, extra early, valuable for mar. ket.

Empire State-White, bunch large, good.

Eumelan-Large, black, good, medium early.

Gaertner-Red, large, showy and good.

Eartford-Black, early, fair quality.

Iona-Red, tender, juicy, high flavored, earlier than Catawba.

jabella-Black, well known.
Ives-Black, small, good.

Jefferson-Red, very large, fine.

Jady -White, ripens with Hartford, valuable.

Lindley, No.9-Red, medium size, high flavored

Martha-White, medium size.

Merrimac-Black, large, sweet and rich, early and good.

Mills-Black, large, meaty, good.

Moyer-Resembles Delaware, but earlier.

Pocklington-White, very large, excellent.

Poughkeepsie-Like Delaware, except larger, eas lier and longer keeper.

Saiem, No. 25-Red, large, very fine.

Ulster Prolific-Red, medium, very productive.

Vergennes-Red, large and good, a great keeper.

Wilder, No. 4-Black, large, fine, good keeper.

Worden-Black, similar to Concord, but better,

Woodruff-Red, hardy and prolific.

Wyoming-similar to Delaware, but larger. 


\section{Currants.}

Black Champion-An English variety of great alue; very sweet and delicious; bushes very thrifty and strong; berries very large; early, prolific, fine.

Black Naples-Large, rich and tender. Excellent.

Cherry-The Standard Red Currant. Fruit very large; a fine upright grower; valuable alike for market and garden; splendid quality.

Crandall-Black. A seedling, said to be free from all attacks of insect enemies. A productive, vigorous grower, usually producing a crop next year after planting. Quality poor.

Fay's Prolific-One of the very best and most popular red currants. It is very productive, hardy and vigorous; it will average larger than Cherry; of the finest quality, and brings best prices on the market; fruit bunches 3 to 5 inches long, easily picked.

Lee's Prolific-One of the best Black Currants. Very early; fruit very large; probably the most productive Black Currant in cultivation. Splendid quality; sweet and good. Plants hardy and vigorous.

North Star-A red Currant from the West. The iruit is too small to be valuable here. A strong grower and very hardy. Said to be productive in the West. Fruit sweet and rich; cluster long, bright,shining red.

Pomona-This new red Currant from Indiana is claimed to be the most prolific currant, with fewer seeds, and sweeter than any of the common sorts. Color a beautiful clear, bright red; about the size of Victoria; easily picked, and hangs a long time after ripe.

Perfection-A new variety of highest excellence, originated at Rochester, N. Y., and awarded the Barry Gold Medal and other first prizes. Color bright red, size of berry and bush equal to Fay; but said to be superior to it in quality and productiveness. Ripens with Cherry or Fay.

Prince Albert-Red; an excellent late variety. Much grown for market.

Red Dutch-Much grown in Wisconsin and the Test, and there considered the hardiest red variety; medium size; good quality, bunch long, an upright grower and very prolific.

Ruby-An old variety, resembling Victoria. Carries fruit and foliage late.

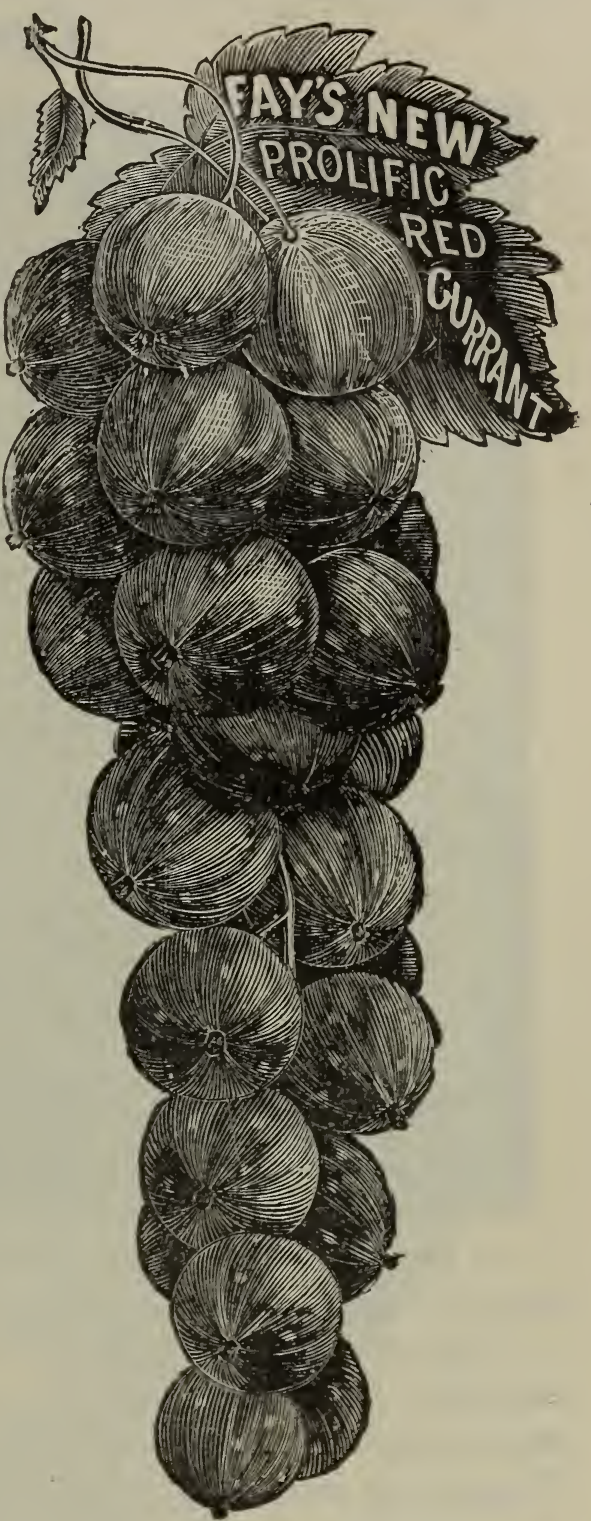

Red Cross-A fine variety of large size, long clusters, and mild, pleasant flavor. Productive

Versailles-Very large, long bunch, brilliant red and of great beauty. Excellent quality.

Victoria-This grand late red variety is one of the best. On rich land it is about as large as Cherry. Bunch very long and tapering; slightly acid, good flavor; ripens late; berries firmly set and remain on the bush a long time in perfect clusters.

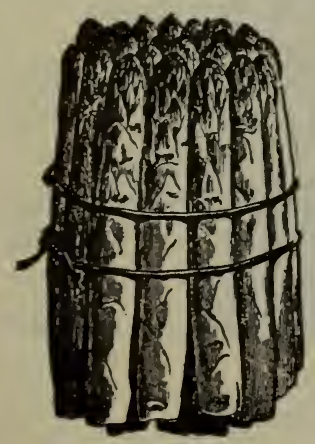

White Dutch-An excellent and well-known sort.

White Grape-A fine white variety; mild flavor; excellent quality, good for table use; very distinct and valuable.

White Imperial-Larger than White Grape and better quality.

Wilder-Red; a new variety of great merit both for table and mar ket. Bunch and berry large, bright rich red and highest quality. grower and productive.

\section{GARDEN ROOTS.}

RHUBARB-Nice Roots.

Myatt's Linnæus. Early Scarlet.

Victoria.

Conover's.

ASPARAGUS-2 Year-Fine.

Palmetto.

Mammoth Whito 


\section{Gooseberries.}

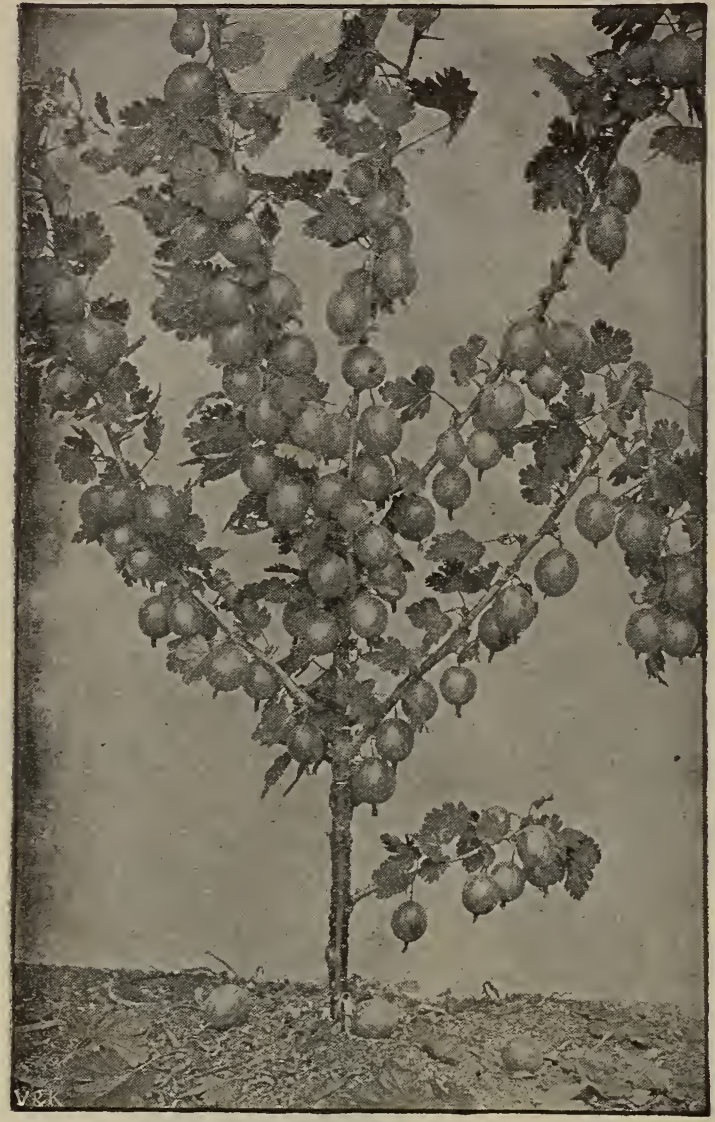

A YOUNG BUSH OF TRIUMPH GOOSEBERRY.

The Gooseberry thrives best on a cool, damp, rich soil. They should be annually pruned and mulched with manure.

The demand for this fruit is con. stantly growing, the expense of cultivation is light, and the returns most satisfactory. Good plants should produce 200 bushels per acre the third year after plant ing and from 300 to 400 bushels the fitt jear.

\section{Best American Varieties.}

Chautauqua-The bush is strong and vig orous, berries light yellow; free from spines and hair; veined and transparent, very sweet and delicious. Fruit 1 to $1 \%$ inches in diameter.

Columbus-An American seedling of the largest size. Yellow.

Downing - Large, oval; very vigorous, hardy; foliage heavy, covering their fruit from the sun, and resisting mildew, bears abundantly. Greenish-white Strong plants.

Golden Prolific-Golden yellow; finest flavor. very productive.

Houghton-Medium size, roundish, oval sweet; reys productive. Pale red.

Pearl-Very hardy, entirely free from mildew; good quality and more productive than the Downing; greenish-white, large berry.

Red Jacket-Bright red; medium size; healthy and very productive.

Smith's Improved-Oval, sweet, excellent, vigorous, healthy, hardy. Light green.

Triumph-The illustration gives an exact idea of its fruitfulness. Color whitish-yellow; frui oval, crisp, tender and of fine quality. Has never shown any mildew.

\section{The Best English Gooseberries.}

Crown Bob-Very large, bright red, good flavor; makes a strong bush.

Industry-Enormous size; dark red or cherry color, with numerous hairs; delicious when ripe It has been fruited in this country for years with success; unequaled for size, flavor, pro ductiveness and vigorous growth.

Keepsake-The fruit is straw-colored, excellent flavor, one of the earliest in cultivation; a largo cropper, vigorous and healthy; foliage very early and dense, giving much protection to its bloom and fruit.

Lancashire Lad-Large, smooth, bright red, fine quality; strong grower and productive. Best for dessert.

Whitesmith-Large, roundish oval, yell wish white, slightly downy, good quality. 


\section{Raspberries-Blackcaps.}

Cumberland-"The Business Blackcap." It is of wonderful productiveness, producing regularly and uniformly very large crops. In size the fruit is simply enormous, far surpassing any other variety. The berries run seven-eighths and fifteen-sixteenths of an inch in diameter. In quality it is similar and fully equal to the Gregg. Although extremely large, it is unusually firm and is well adapted for long shipments. It is an unusually strong grower, throwing up stout, stocky canes, well adapted for supporting their loads of large fruit.

Black Diamond-A large, handsome berry of great productiveness and splendid keeping and evaporating qualities; or $€$ of the most profitable to grow. Sweet anü excellent.

Conrath-One of the mostreliable medium sorts, especially valuable for evaporating.

Earhart (Everbearing)-Good awality, robust grower, very hardy.

Eureka-Large, black, free from bloom, excellent quality, strong grower, hardy and productive. Ripens with Palmer.

Gault-A remarkable berry, fruiting in the regular season and then again heavy on young shoots in October. Fruit large size, ripens with Gregg; color rich black; fine flavor.

Gregg-The standard late sort. Very large, strong and thrifty. Hardy and good yielder.

Hilborn-Large, jet black, best quality, hardy and prolific. Ripens nearly a week later than Souhegan, and bears a long time.

Kansas-Jet black, firm and delicious-as large. as the Gregg, quite early. One of the best.

Mammoth Cluster-Large, very productive; good quality; ripens before Gregg.

Ohio-The standard early berry. Very productive. Fine quality; very hardy.

Palmer-A fine early Blackcap. Fruit large, splendid quality. Ripens with Souhegan.

Souhegan-Large, black, very early medium quality, very hardy and a great bearer.
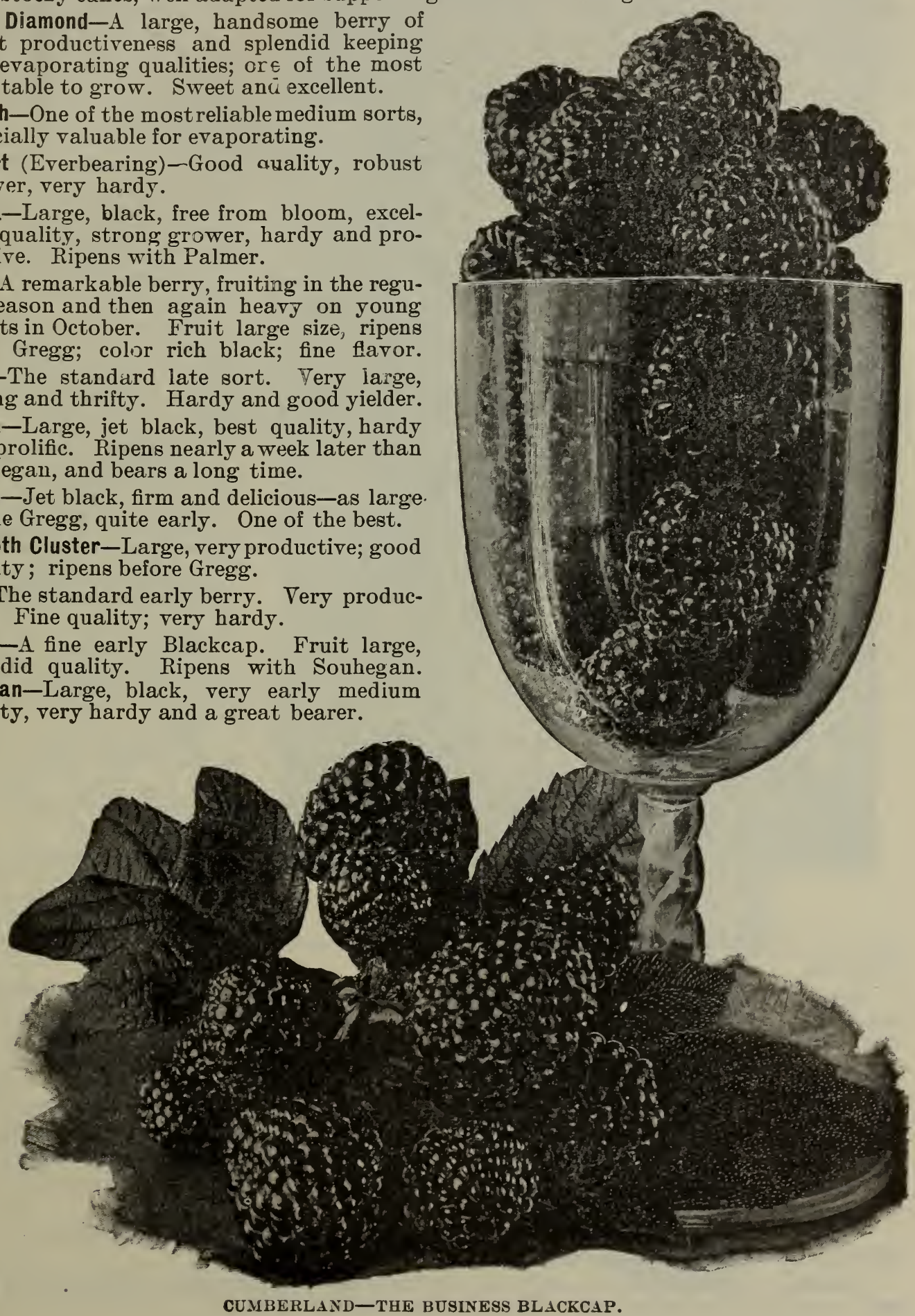


\section{Raspberries.--Red Varieties.}

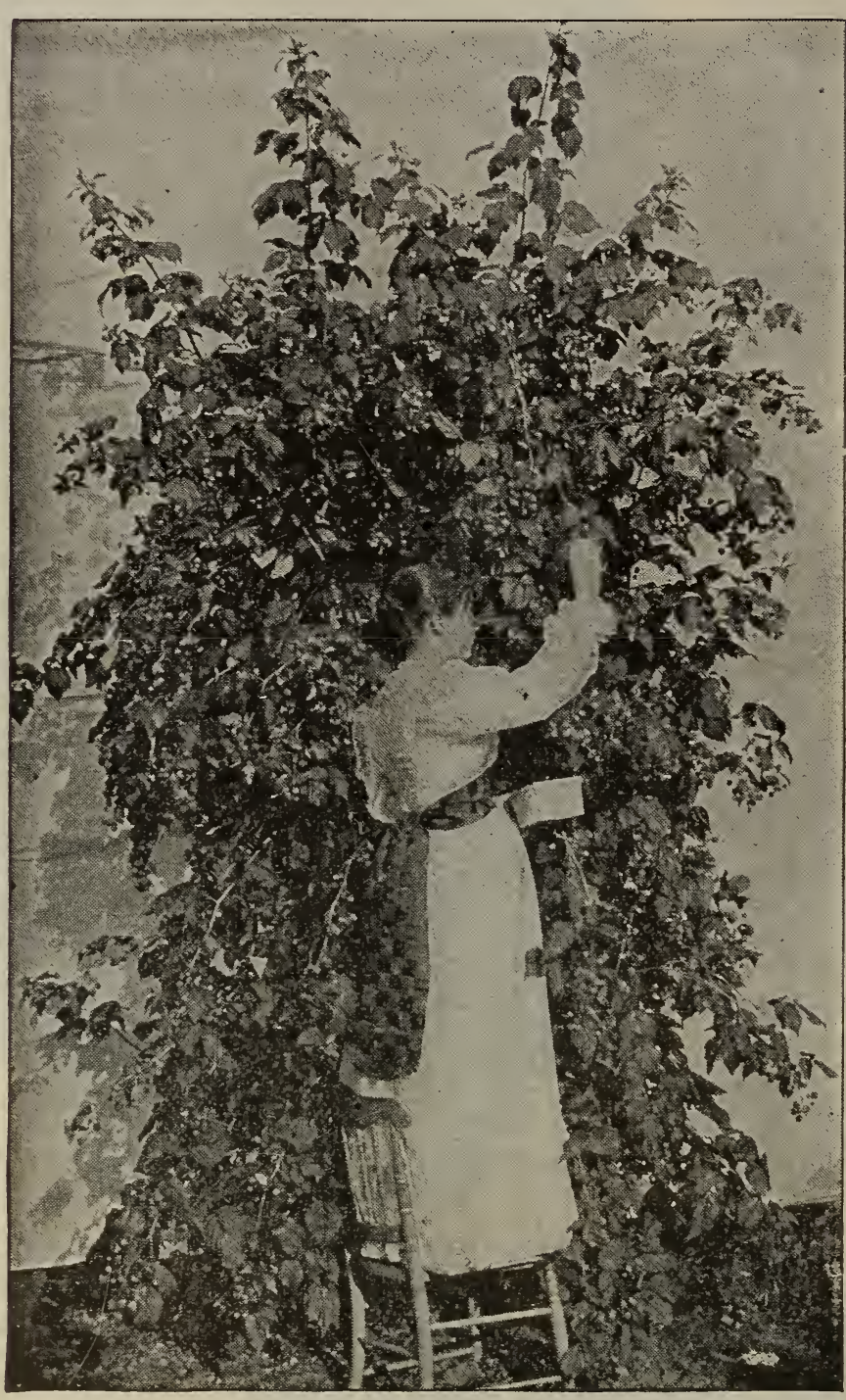

COLUMBIAN.

St. Regis-A real everbearing variety of sterling merit, bearing from June to October or November. Berries large and handsome and well flarored to the very last. Usually bears a crop the first season planted.

Columbian-A seedling of the Cuthbert, grown near the Gregg Blackcap, and believed to be a cross between the $t w o$. A vigorous grower, canes 10 to 16 feet in length and often over an inch in diameter; fruit large; color dark red bordering on purple: adheres firmly to the stem; a most delicious table berry. Best for canning purposes.

Brandywine-Large, bright red, firm and good.

Cardinal-This new variety originated in Kansas. It is quite as vigorous and productive as Columbian, and quite equal to it in quality. Highly recommended.

Caroline-Pale salmon, large and fine quality.

Clarke-Large, light red, righ flavored. A strong grower, hardy and productive.

Cuthbert-Cane tall, vigorous, healthy. Fruit bright crimson; firm.

Golden Queen-Very large; color rich yellow; vigorous, hardy, productive, splendid quality.

Herstine--Large, roundish conical, light crimson, rich flavor and highly perfumed; a strong grower, hardy and productive.

Japanese-(Wineberry) - Ornamental both in fruit and plant. Bears an abundance of beautiful wine colored fruit of medium size and brisk sub-acid flaror, which is resained when cooked. Esteemed for canning, preserves, jellies, etc.

King-Pronounced by many as the best early red raspberry. Plant a strong grower, very hardy and productive. Berry firm, good shipper, large size and beautiful bright scarlet color; ripens with the earliest.

Loudon-The best all-round market Red Raspberry. It is a wonder in productiveness; bright color, perfectly firm, and of the largest size. It is pronounced by E. S. Carman, of The Rural New Yorker, as the best Red Raspberry. The canes are strong, vigorous and hardy.

Marlboro-One of the hardiest, earliest, largest and best market red berries. Fair quality, handsome color, great bearer, very vigorous and largely planted for market.

Miller's Red--Berry round, bright red, core very small; does not crumble, quite firm. Undoubtedly a vaiuable early berry.

Superlative-Fruit large and very long; color bright red; firm, rich, sugary, delicious; large heavy clusters, ripening well together.

Shaffer's Colossal-A fine purple berry for canning or evaporating. It is a strong grower and produces an immense crop of fruit. It does not market well. 


\section{Blackberries.}

Rathbun-Fruit very large, with small seeds, no hard core. Sweet, luscious, high flavor; color jet black; firm. Berries will measure an inch and a half long. Plant strong, erect. Roots at the tips like the blackcap; hardy and prolific. Forty-five berries filled a quart Strawberry box.

Agawam - Fair size; jet black, tender, melting.

Ancient Briton-Medium, melting, without core; hardy and prolific. Valuable.

Early Harvest-Small size, fair quality and very eariy and productive. Ships well and valuable where it succeeds.

Early King-Good quality, hardy and productive. One of the first to ripen. Valuable for market.

Gldorado-A strong growing hardy variety; very productive, fruit very large, jet black, in , थrge clusters, ripening well together. Its kseping quality is unsurpassed. Finequality, 8 w eet, without core.

Erie- Fruit of the largest size; not entirely hardy, strong, healthy grower; free from disease; pr sductive; very early, ripening before the Wilson; extra quality; good shipper.

Kittatinny-Large, slightly conical, shining black, sweet, rich and excellent. One of the best.

Lawton-(New Rochelle)-Large, sweet and juicy. An old and popular sort.

Logan-A decided novelty, being a hybrid between a raspberry and blackberry, and partakes of the flavor of both. Fruit large as the blackberry and of same shape; color dark maroon red when fully ripe. Pleasant, mild and vinous. Hardy.

Lucretia Dewberry-A trailing Blackberry; fine flavor, very prolific, large fruit.

Mersereau-A new berry of sterling qualities. Large size, good quality, hardy and productive. Highly recommended.

Snyder-Early; good quality; immensely prolific; fair size, black, fine; one of the hardiest.

Taylor-Perfectly hardy; large, highest quality, with a rich flavor; strong, spreading growth, productive.

Wilson-Large; luscious, sweet, early and hardy.

JUNEBERRY - A good substitute for the huckleberry. The fruit is borne in clusters, and is reddish purple in color, changing to a bluish black. In flavor it is mild, rich sub-acid.
RATHBUN

BLACKBERRY. Fruit of Highest Quality. Largest Size, Handsome Very Productive Commands Highest Price. in Market. 


\section{Strawberries.}

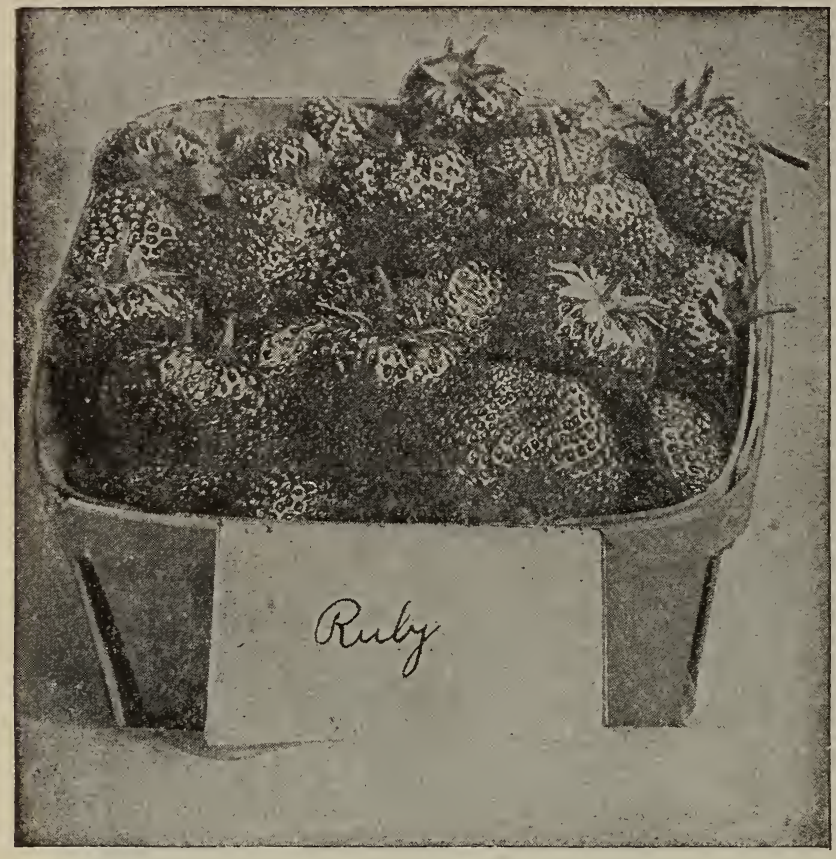

We offer only the finest varieties of Strawberries, including the latest improvement in this valuable fruit.

Fertilization-Varieties marked(P) have imperfect flowers and need other perfect flowered sorts planted every two or three rows to fertilize the blossoms. If only one kind is wanted, choose a perfect flowering sort.

Ruby-We believe the Ruby to be one of the best varieties ever offered. The piant is vigorous, large and strong: very iealthy, and makes a clean, full row. Foliage rich, dark green. In ordinary field culture, along side of Warfield, Bubach, Haverland, Green. ville, etc., it has proved itself a better berry in every way. Fruit large, somewhat irregular but not coxcombed, dark red clear through, sometimes with white tips; retaining its color when canned. Very best quality, rich, firm and abundantly productive. A fine keeper and shipping berry.

Bismarck-Plant resembles $\mathrm{Bu}$. bach, but more robust and stocky, with thesame ironclad foliage. Fruit produced in abundance, outyielding Bubach. Shape obtuse, conical, never coxcombed; the heaviest, most solid berry ever grown or handled. Color bright scarlet, no green tips, very firm, good flavor, season medium to very late, size larger than Bubach. Perfect blossom. Give it good strong soil and be surprised and pleased with its immense crop of large,luscious berries.

Brandywine-Berries very large, regular, conical form; color bright glossy red; flesh firm and of very excellent quality. Its very large size, beauty of form and color, firmness and high quality will make it a desirable variety for any purpose.

Clyde-A new berry that is making a record wheraver grown. Season early to medium. Perfect flower, berries large to medium, very firm, dsik scarlet in color, fine flavor.

Glen Mary-Berries large, bright deep red, rich, sweet and good. One of the most produc. tive and holds its size well to the end. Medium to late.

Marshall-Color very dark rich crimson to the core, flesh fine grained and of a delicious flavor and with the peculiar aroma of the native wild strawberry. It is a remarkably fine keeper and carrier, which will commend it to all growers for the market.

Margaret-Very productive; fruit large, a dark glossy red. Firm, very even in shape. Medium to late; plant large and strong; extra quality.

Mckinley-A superior berry, remarkable for size, shape, color and qnality. Plant vigorous healthy and a great yielder. Season medium to late.

Nick Ohmer-Plant very large and stocky, vigorous and productive; fruit the very largest size, a giant among strawberries. It is never misshapen. Its only departure from the regular, roundish, conical form is when, under high culture, it is somewhat triangular. Dark glossy red, firm and of excellent flavor. oarlier.

Seaford-(P)-As large as Bubach, but ripens its fruit much faster and is several days

William Belt-Berries large, conical, rather long, regular in outline; bright red, glcrss; quality good, moderately firm. Plant vigorous, healthy and quite prolific.

\section{ADDITIONAL VARIETIES.}

Beder Wood.

Bubach No. 5, (P).

Crescent.

Cumberland.

Downing.

Greenville, $(\mathrm{P})$.
Gandy.

Haveriand.

Jessie.

Lovett.

Michel's Early.

Parker Earle.
Sharpless.

Timbrell,

Triomphe de Gand.

Warfield.

Wilson. 


\section{Ornamental Trees.}

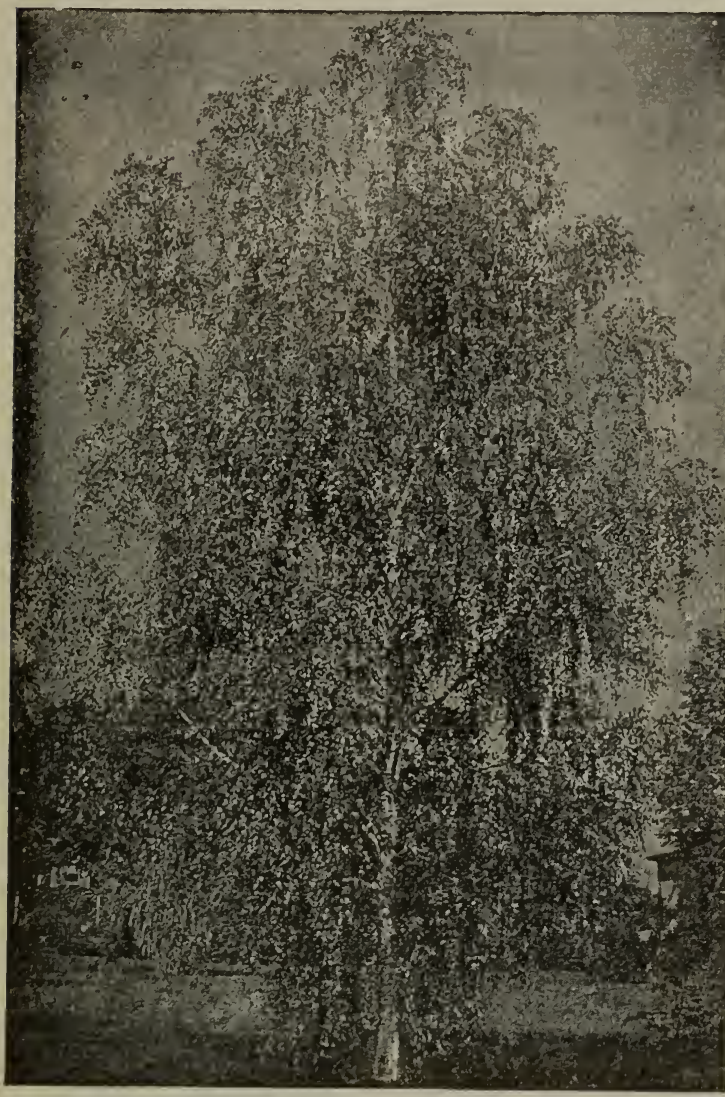

CUT-LEAF WEEPING BIRCH.

Ailanthus (Tree of Heaven)-A lofty grow ing tree, with long feathery foliage; gives a very tropical effect.

Alder (Common)-A rapid growing tree suitable for moist land; attains 30 to 60 feet when grown.

Alder, Imperial Cut-leaf-A stately tree of graceful habit. Vigorous; hardy.

Ash (American White)-Our well-known na tive tree.

Beech (American). A handsome lawn tree.

Beech, Fern-leaved-A tree with elegant cut leaf foliage.

Beech, Weeping-Very noble and effective.

Beech, Purple-leaf-A beautiful lawn tree with purple foliage; attains 40 to 50 feet

Birch (Common white). Very desirable.

Birch, Cut-leaved Weeping-One of the most elegant of all weeping trees. Its tall, slender, yet vigorous growth, graceful drooping habit, silvery white bark and delicately cut foliage present a combina tion of attractive characteristics rarely met with in a single tree.

Birch, Purple-Leaved-Rich, purple foliage.

Birch, Young's Weeping-The most beauti. ful weeping tree grown. Trails upon the ground.

Catalpa, Speciosa-One of the most beautifu] lawn or street trees, producing magnificent flowers early in spring; very rapid growing; beautiful.

Catalpa, Bungei-A fine umbrella-headed tree, 8 to 10 feet high.

Catalpa, Teas' Japan-Vigorous, upright growth; large, luxuriant foliage; handsome white flowers and a delicate fragrance when the tree is in bloom.

Cedrela Sinensis-A beautiful species from China. Excellent for city planting.

Cherry, Double-flowering-A fine, upright tree, producing double white flowers in May.

Cherry, Japan Weeping-Very pretty, rose-colored flowers. Slender branches, which droop gracefully to the ground. Undoubtedly one of the most desirable weeping trees.

Crab (Chinese Double-flowering) - Beautiful; white and rose-colored flowers in May.

Crab, Bechtel's Double-flowered (American)-Tree medium size, covered in early spring with beautiful double pink tragrant flowers that look like roses at a distance.

Dogwood, White-flowering-Flowers three inches in diameter, produced in spring before the leaves appear; very showy. Spreading, irregular form, growing 20 to 25 feet high.

Dogwood, Red-flowering-The same as above, only a bright, fresh, cheerful red.

Dogwood, Weeping-A weeping form of the White Dogwood, distinct from all other weeping trees; makes a magnificent specimen, either summer or winter.

Elm. American White-A noble, drooping, spreading tree of our own woods; one of the grandest of park and street trees.

Elm, English -A tall, erect tree, 40 to 50 feet high when grown.

Elm, Camperdown Weeping-Grafted 6 to 8 feet high, this forms the most picturesque of drooping trees. The leaves are large, dark green and glossy.

Elm, Huntingdon-Very desirable; erect, rapid grower; bark clean and smooth; 40 to 50 feet high.

Elm, Scotch-A fine spreading tree; rapid grower. 40 to 50 feet high.

Horse Chestnut-The well-known species; has magnificent spikes of white flowers.

Horse Chestnut Double White-flowering-Very fine and rare. 
Horse Chtstnut, Red-flowering-Showy red flowers; makes a large tree; very handsome.

Judas Tree, or Red Bud (American) -A small tree, covered with pink flowers early in spring before the leaves appear. Very attractive and beautiful.

Judas Tree (Japanese)-Like above, but larger flowers; very attractive.

Laburnum (Golden Chain)-A fine tree, growing 15 to 20 feet high, with long racemes of golden flowers in June.

Larch-A rapid growing tree, with small drooping branches, 30 to 40 feet high.

Linden (American Basswood)-A rapid growing, native tree, with very large leaves and fragrant flowers.

Linden, European-A pyramidal tree, with large Jeaves and fragrant flowers.

Linden, White-leaved-Large, handsome foliage, white underneath, green above. 20 to 25 feet high.

Magnolia, Acuminata-A beautiful pyramidal tree, attaining a height of from 50 to 80 feet; has yellow flowers, tinted with purple, in June.

Magnolia, Conspicua - A beautiful variety, withlarge white flowers that appear before the leaves. Tree of small size; very handsome.

Magnolia, Lenne-Flowers cup-shaped, crimson-purple outside and pearl-colored within.

Magnolia, Soulangeana-Flowers white and purple; foliage large, glossy and massive; very profuse; hardy and one of the most desirable.

Magnolia, Speciosa-Flowers smaller than Soulangeana; blooms later; hardy and desirable.

Maple, Ash-leaved-A fine, rapid growing variety; very hardy, and excellent for avenues.

Maple, Norway-A distinct foreign variety, with large, broad leaves of the deepest green. It retains its leaves long after other trees are bare.

Maple, Purple-leaf Sycamore-Foliage green above and reddish-purple beneath. 15 to 20 feet high.

Maple, Scarlet-Red flowers; foliage changes to a brilliant scarlet in autumn.

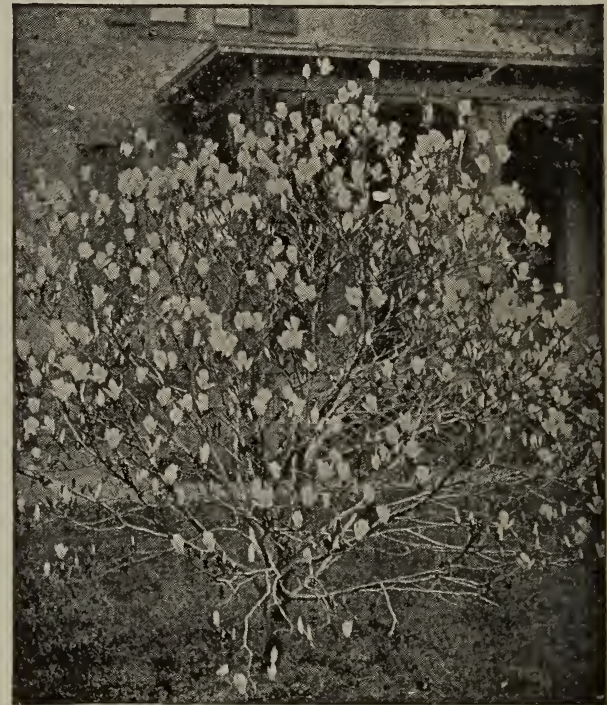

MAGNOLIA CONSPICUA.

Maple, Schwedler's-A variety of the Norway. The young shoots and leaves are a bright crim. son, changing to a purplish-green when grown.

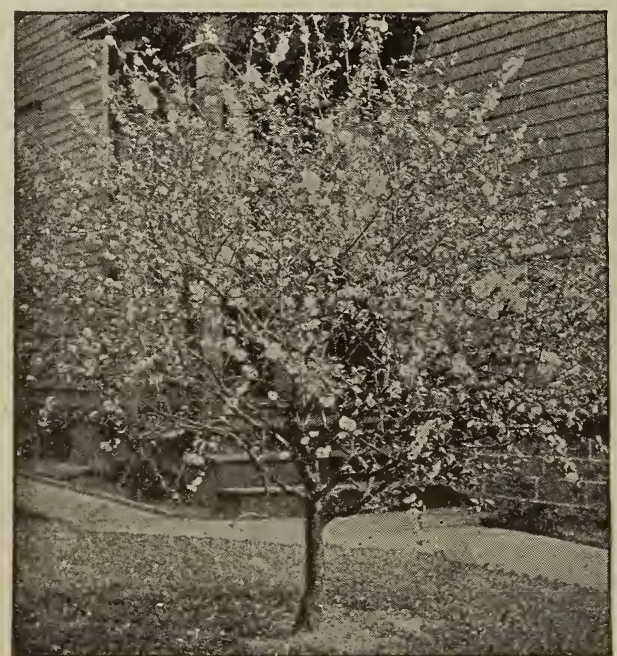

PEACH, DOUBLE FLOWERING.

Maple, Silver-leaved-An excellent shade tree of rapid growth; desirable for quick effects.

Maple, Sugar-A very popular tree both for lawns and avenues; symmetrical.

Maple, Weir's Cut-leaved-A variety with cut or dissected foliage; branches slender and drooping, almost as graceful as the cut-leaved birch. The foliage is silvery underneath.

Maple, Japan-Small and shrubby, foliage bright green changing to crimson in autumn.

Maple, Japan Purple-leaf-A bushy shrub, with dark purple foliage. Effective.

Maple, Cut-leaf Purple, Japan-Dwarf and weeping, leaves rose color, changing to a deep purple. Leaves deeply cut, wood crimson colored. Very attractive.

Maple, Blood-leaved-One of the most striking and beautiful of the Japan Maples.

Mountain Ash (American)-A fine ornamental tree with bright scarlet berries.

Mountain Ash (European) -A fine hardy tree; head dense and regular, covered from July till winter with great clusters of bright red berries.

Mountain Ash, Oak-leaved-Similar to above with oak-shaped leaves. Smooth and clean. 
Mountain Ash, Weeping-Very odd and attractive; covers the ground completely, making a perfect shade.

Mulberry (Downing) Everbearing-Berries mild and pleasant. Bears at four and five years of age; continues in fruit from July to September.

Mulberry, Hicks' Everbearing-Rapid growth and produces immense quantities of excellent fruit, which ripens over a period of three months.

Mulberry, New American-This we consider equal to Downing in all respects, continuing in bearing fully as long, and. a hardier tree; fruit jet black.

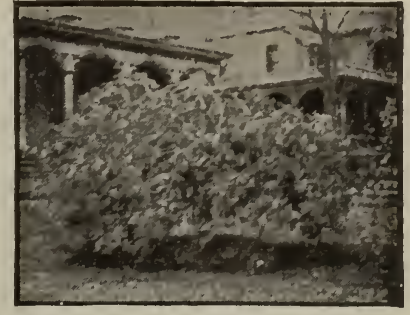

WEEPING MOUNTAIN ASH.

Mulberry, Russian-Very hardy; much used for hedges and wind breaks.

Mulberry, Teas' Weeping-Perfectly hardy, forming a natural umbrella-shaped top or head: foliage handsome; a fine ornamental for the lawn.

Oak (American White) $-A$ large, fine native tree.

Oak, Burr or Mossy Cup-A noble native tree; foliage very large and fine.

Oak, English-The Royal Oak of England; slow spreading growth.

Oak, Golden-A fine growing tree with bright golden-yellow foliage.

Oak, Pin-A rapid growing tree, foliage deep green. Becoming very popular.

Oak, Scarlet-A native tree with bright scarlet foliage in autumn.

Peach (Double-flowering, white or red)-Flowers perfectly double, covering every branch with a mass of beautiful flowers early in Spring. Makes trees 8 to 10 feet high.

Plane Tree (Sycamore or Buttonwood)-A well-known tree with heart-shaped leaves.

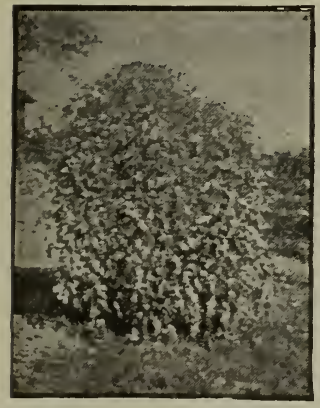

TEAS' WPG. MULBERRY.

Plane, Oriental-Similar to above, but a better and more compact grower. Very hardy.

Plum, Purple Leaf (Pissardi)-Perfectly hardy; the leaves are rich purple, retaining their bright color through the entire season. Profusion of white blossoms in May, followed by small purplish-red edible fruit.

Poplar, Carolina-A native tree of rapid growth, with large, glossy leaves; valuable for park or street planting; a fine shade tree.

Poplar, Lombardy-Very distinct, remarkable for its erect growth and tall, spire-like form.

Poplar. Silver-leaved-Very rapid grower; leaves dark rich green above and white beneath.

Salisburia (Maiden Hair)-From Japan; fern-like foliage; tree medium size; rare and fine.

Sweet Gum (Liquidambar) - A striking tree, with deep crimson foliage in autumn.

Tulip Tree (Whitewood)-One of the grandest of our native trees, of tall pyramidal habit, with broad, glossy, violin-shaped leaves and tulip-like flowers.

Thorn, Double White-A beautiful flowering tree, with small double daisy-like flowers in May and June; very fine for lawns.

Thorn, Double Crimson-Fine double daisy-like crimson flowers.

Thorn, Paul's Double Scarlet-Flowers deep crimson, with scarlet shade; very double.

Yellow Wood-A fine native tree, flowers pure white, fragrant; blooms in great profusion.

Walnut-See nuts, page 13.

Willow, Babylonian-W seping Willow. Tall, graceful and drooping; very beautiful.

Willow, Golden-A variet.y with yellow bark.

Willow, Kilmarnock-A graceful weeping tree, with glossy green foliage.

Willow, New American-Grafted 5 to 6 feet high, it makes a very ornamental weeping tree, with long slender, graceful branches and delicate leaves.

Willow, Rosemary-leaved-Grafted 5 to 7 feet high, it makes a striking round-headed tree; branches feathery with silvery foliage.

Willow, Wisconsin-A large tree with long, drooping branches, similar to Babylonica, but hardier.

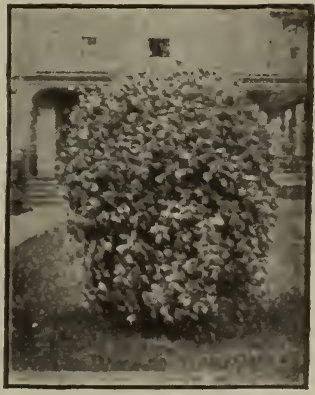

RILMARNOCK WILLOW. 


\section{Evergreens.}

Arbor-Vitæ (Thuja occidentalis)-This is the finest of all evergreens, valuable for hedges. hardy, easily transplanted; nursery specimens rarely fail. It soon forms a beautiful, dense hedge.

Arbor-Vitæ, Douglas' New Golden-The most desirable new Golden variety, especially for the Northern States. Hardy and a free grower, with fine golden-yellow foliage.

Arbor-Vitæ, Golden-Nearly spherical in outline and with bright vellow tinged foliage.

Arbor-Vitæ, Pyramidalis-The most beautiful of all the Arbor-Vitæs, having dark green, compact foliage and remarkably erect form; perfectly hardy.

Arbor Vitæ, Rosedale-Hardy, effective and handsome.

Arbor Vitæ, Siberian-The best species native to that country; exceedingly hardy; keeping its color well in winter; growth compact and pyramidal.

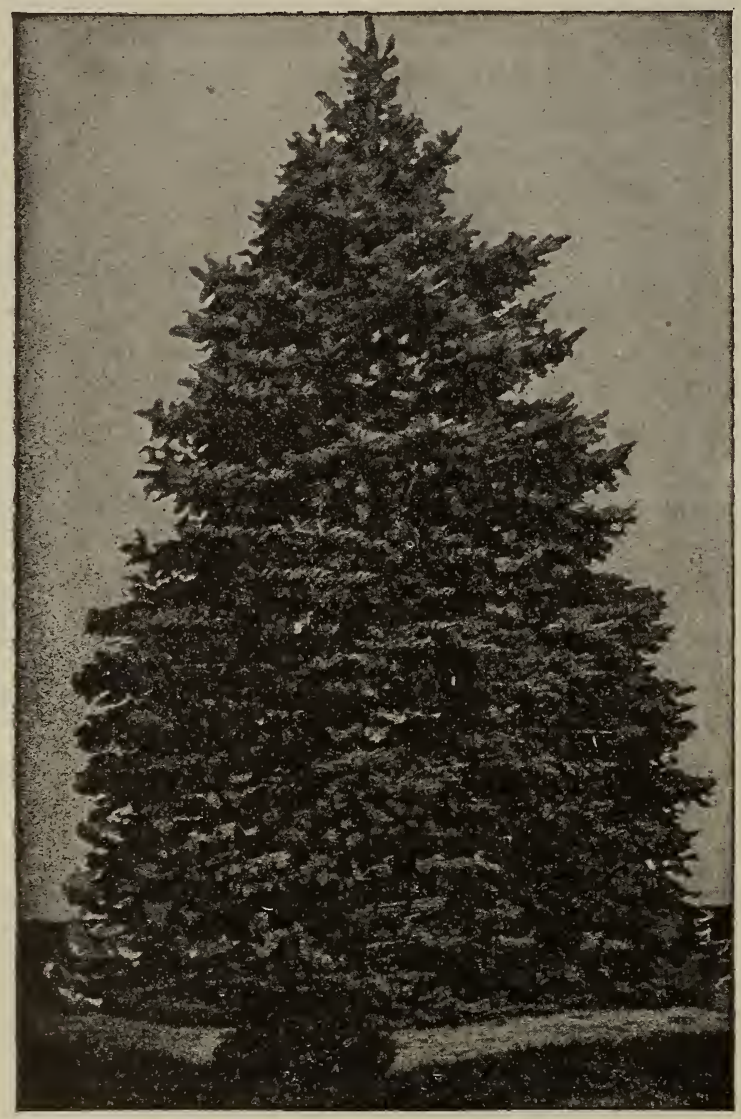

COLORADO BLUE SPRUCE.
Arbor-Vitæ, Tom Thumb-A very small compact little evergreen, with very fine foliage. It makes a beautiful ornament for a small yard or cemetery lot, and is fine for low hedges.

Fir, Balsam-A well known and popular tree. Beautiful and in every way desirable.

Fir, Nordman's Silver. One of the finest. Juniper, Irish-A very pretty little tree.

Juniper. Sabin-A low, wide-spreading shrub.

Pine, Austrian-Hardy and valuable.

Pine, Scotch-Rapid growing and valuable for screens.

Pine, White-The well known forest tree. Handsomest of native species.

Spruce, Colorado Blue-The finest of evergreens. One of the most beautiful and hardy of the spruces; foliage a rich sky blue; very handsome.

Spruce, Douglass-Conical and spreading.

Spruce, Hemlock - An elegant tree with drooping branches and fine yew-like foliage. Makes a fine ornamental hedge.

Spruce, Norway-Of rapid growth and graceful drooping habit. One of the best for hedges and screens.

Spruce, Weeping-A beautiful variety resembling Norway but with pendulous drooping branches. Fine.

\section{HEDGING-DECIDUOUS.}

Buckthorn, California Privet, Honey Locust, Japan Quince, Osage Orange, Spireas, Tamarix.

\section{HEDGING--EVERGREEN.}

American Arbor-Vitæ, Siberian Arbor-Vitæ, Mahonia, Norway Spruce, Austrian Pine, Scotch Pine, Tree Box.

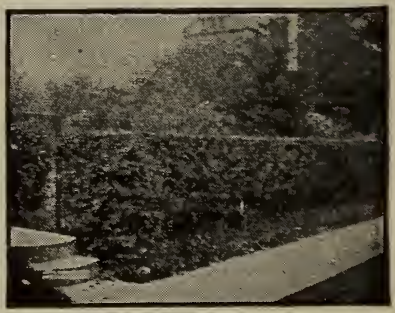

CALIFORNIA PRIVET. 


\section{Ornamental Shrubs.}

Flowering Shrubs are most valuable among the ornamentals, whether planted in massee or single specimens. They are indispensable in the parks, the city garden, or the country home. A judicious selection will give abundance of bloom the entire season.

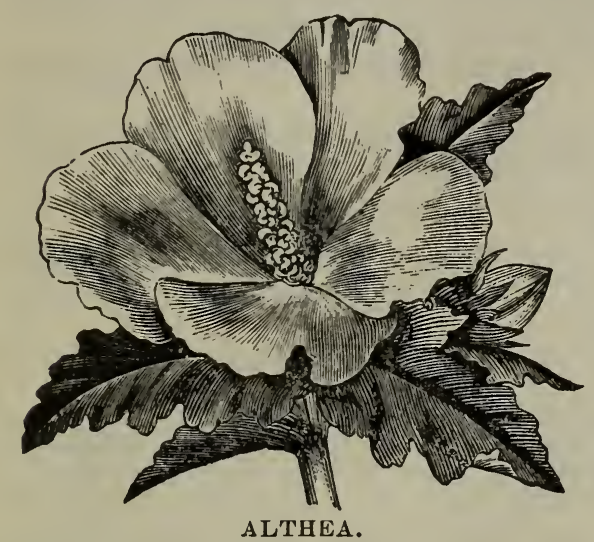

Althea (Rose of Sharon)-One of the most showy flow. ering shrubs, strong, erect growing, with large, bellshaped flowers of striking colors, borne abundantly in August and September, when most other shrubs are out of bloom. White, red, rose, purple, blue and variegated. Single and double.

Althea, Tree Form-Same as above, but grown in tree form. 4 to 5 feet high, very unique and attractive. All colors.

Althea, Variegated-leaved-Double purple flowered Showy and desirable.

Almond-Beautiful double flowers in May. White and red.

Aralia, Japonica (Angelica Tree)-A handsome shrub from Japan; flowers white, in large spikes, in September.

Aralia, Spinosa (Hercules Club) - A native plant valuable for proảucing tropical effects.

Azalea (Ghent)-A hardy variety, with delightful perfume, blossoming during May and June. They do well in any rich garden soil, but do best in light moist ground enriched with leafmould. A good assortment of colors.

Azalea (Mollis)-A beautiful species from Japan, with iarge flowers of fine shape, perfectly hardy. Colors orange, yellow and carmine.

Barberry, Purple-leaved-Foliage and fruit of a violet purple color, very striking; fine for single specimens; also desirable for ornamental hedges.

Barberry, Thunberg's-Dwarf habit, small foliage, changing to a beautiful red in autumn.

Bladder Senna-A large shrub of compact growth with small foliage and yellow pea-blossom shaped flowers in June followed by reddish pods.

Broom (Genista)-Golden-yellow blossoms in June. Fine for rockeries and dry hills or fixing steep banks.

Calycanthus (Sweet-Scented Shrub)-Very desirable; the wood is fragrant, foliage rich, flowers of a rare chocolate color, deliciously fragrant; blossoms in June and at intervals thereafter.

Clethra Alnifolia (Sweet Pepper Bush)-A desirable shrub, with dark green foliage and show y spikes of creamy-white fragrant flowers.

Cornus Elegantissima-A variety with dark green foliage, margined with silver and red; wood dark red. A beautiful and attractive free-flowering shrub.

Cornus Mascula, Variegated-The foliage is beautifully variegated wit?. white.

Cornus Sanguinea (Red-branched)-A strong growing shrub, with ilusters of fine white flow ers, stem and branches turning blood-red in winter.

Currant, Flowering-A gay shrub in early spring. Crimson and yellow flowered.

Daphne (Garland Flower)-A dwarf shrub with bright pink flowers, blonms very early.

Deutzia, Crenata-Very beautiful and desirable; flowers double white, tinged with rose.

Deutzia, Gracilis-Dwarf; white flowers in June. Very beautiful.

Deutzia, Lemoinei-Pure white flowers, upright growth. Habit dwarf and free flowering.

Deutzia, Pride of Rochester-Very large double white flowers. It excels in size of flower, pres fuse bloom and vigorous growth; nearly a week earlier than Deutzia Crenata.

Deutzia, Watereri-A new form of Crenata with very double pink flowers.

Flder-Large, attractive shrubs, adapted to moist soils and sbow. in foliage and fruit. 
Elder, Golden (Sambucus Aurea) -A beautiful shrub, with golden-green foliage, when planted in the sun. Very valuable.

Eleagnus Longipes-A handsome, shapely silver-leaved shrub, perfectly hardy and easy to grow. The bright yellow flowers appear in June and are followed by edible fruit, which is produced in the greatest abundance along the whole length of the branches, oval in shape and about one-half inch long; color deep orange red, very showy and attractive.

Exorchorda (Pearl Bush)-A fine shrub, producing white flowers in May. Very beautiful.

Filbert, Purple Leaf-A beautiful shrub. Large dark purple leaves; distinct and fine.

Forsythia (Golden Bell)-A medium sized shrub, with drooping yellow flowers early in spring, before the leaves; very fine.

Fringe, Purple-A beautiful, distinct shrub, with large bunches of feathery flowers which give the tree the appearance of being covered with a cloud of smoke.

Fringe, White-A fine shrub, with delicate fringe-like greenish-white flowers in May.

Hedysarum-An exceedingly graceful shrub, introduced from Mongolia, with delicate foliage and deep violet-red blossoms borne in racemes 12 to 18 inches long, throughout the sum. mer. Requires protection in winter in severe latitudes.

Honeysuckle (Upright or Tartarian)-Beautiful rose, red or white flowers in June.

Hydrangea Paniculata Grandiflora-Hardy in all sections of the country and very easy to grow. The flowers will be larger and finer if given good rich soil. The flowers are immense, greenish-white when first open, changing to pure white and turning pink with age. Commences to flower in July and remains in flower until November.

Hydrangea, P. G., Tree Form-Same as above, but grown in tree form with single stem. Tery fine and desirable.

Hydrangea, Otaksa-Large trusses of rose colored flowers. Must be wintered indoors

Hydrangea, Red-branched-Immense heads of deep rose flowers; red branches; tender.

Hydrangea, Tom. Hogg-Flowers pure white; borne in great profusion; tender.

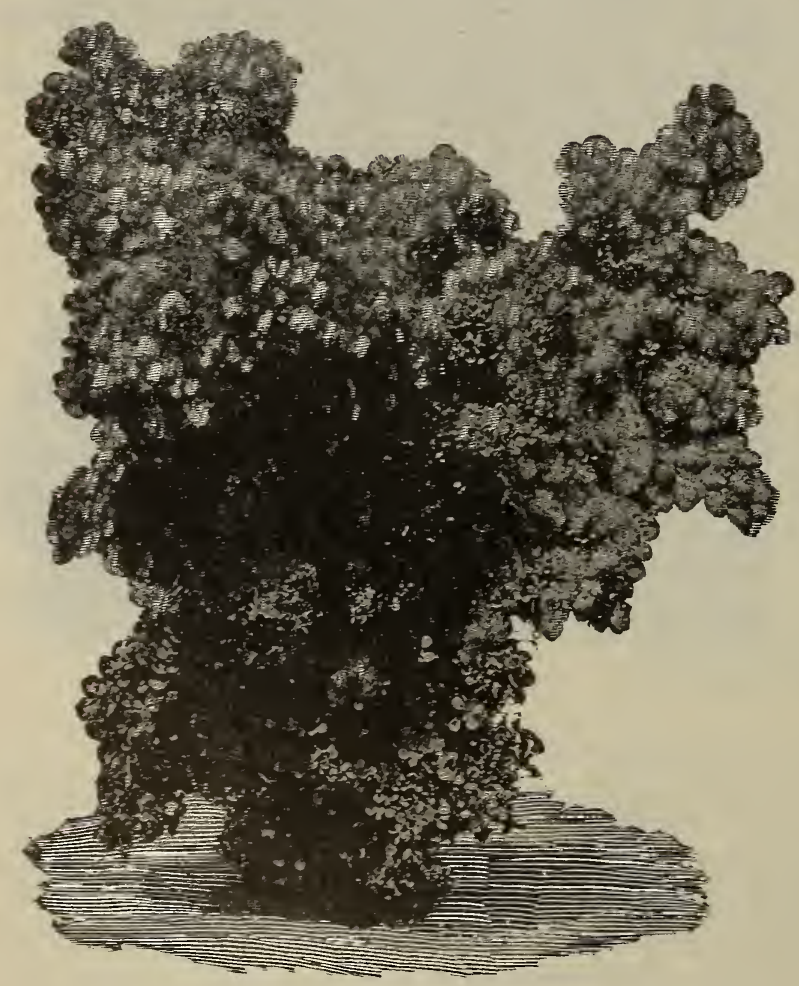

PURPLE FRINGE, OR SMOKE TREE.
Kerria, Japonica (Corchorus, Globe Flower)-A slender, green-branched shrub, 5 to 6 feet high, with yellow flowers from June to October.

Lilac, Chas. X-Dark red. Immense trusses, strong grower. Beautiful.

Lilac. Chinese Weeping-Of graceful drooping habit; flowers white, double and intensely fragrant.

Lilac, Frau Dammann-Pure white. Immense trusses, very fine.

Lilac, Japanese Tree-A remarkable new specier, becoming a good sized tree. Foliage dark glossy green; flowers small and feathery but formed in great panicles. Blooms a month later than other lilacs.

Lilac, Leon Simon-Very double; bluish crimson; an extraordinarily beautiful variety.

Lilac, Ligustrina Pekinensis-A tall shrub of much beauty. Flowers white, with an odor of honey.

Lilac, Ludwig Spaeth-Truss very large, dark purple. Superb.

Lilac, Marie Legraye-White, large trusses.

Lilac, Michel Buchner-Dwarf habit, bearing rigid pyramids of bloom at top of all its branches. Pale lilac; magnificent Lilac Villosa.

Lilac, President Grevy-Blue double flowers, very large, fine.

Lilac, Persian-Slender growth and finer foliage than the common lilac; purple or white, in large spikes.

Lilac, Rothomagensis (Rouen)-Intense violet. Large neads. Fine. 
Orange, Hardy (Limonia Trifoliata) - A very ornamental shrub, perfectly hardy, with hand. some foliage and fragrant white flowers, followed by orange-red fruit. Excellent for hedges.

Orange, Otaheite-A beautiful pot plant, bearing fragrant blossoms and edible fruit.

Pæonia, Moutan-Flowers of enormous size and gorgeous colors. Colors white, red, crimson and pink. Very effective.

Pæonia, Tree-A handsome flowering shrub, growing 6 to 8 feetin ten years, bearing gorgeous flowers of immense size in May. Colors blush, rose and white.

Pavia (Dwarf Horse Chestnut)-A spreading shrub with large showy spikes of flowers late in June.

Plum, Double Flowering (Triloba)-Flowers semi-double, of a delicate pink, upwards of an inch in diameter, thickly set on the long, slender branches. Hardy.

Privet, California-Vigorous, hardy, almost evergreen; a fine shrub. Makes a valuable hedge.

Quince, Japonica Columbia-A remarkable new form, bearing a greenish-yellow fruit resembling the Bellflower apple. Fruit very fragrant and makes a jelly equal to the well known Guava. Very ornamental as well as useful.

Quince, Japan-A hardy shrub; bright red flowers in early spring. Very beautiful on the lawn or in hedges. White flowering also furnished if desired.

Scorpion Senna (Coronilla)-A low, round shrub with intensely green glossy leaves and pretty reddish-yellow flowers in May. Very choice and desirable.

Silver Belı (Snowdrop Tree, Halesia)-A beautiful large shrub with pretty white bell-shaped flowers in May. Very desirable.

Snowball, or High Bush Cranberry (Opulis)-Handsome and dense foliage; flowers white, in drooping cymes, followed by brilliant scarlet edible berries which hang until late in the winter.

Snowball (Viburnum)-The common large white snowball.

Snowball, Japan-An erect, compact shrub, blooming in June, the plants being completely cor. ered with large balls of flowers as white as snow. The foliage is a dark green.

Spirea, Anthony Waterer-A new dwarf, flowered variety, 15 to 18 inches high, crimson flowers. Perfectly hardy; it makes a fine, compact plant.

Spirea Billardi-Fine foliage, with spikes of red colored flowers during summer and fall.

Spirea Bumaldi-A fine Japanese variety of dwarf, compact habit, covered during midsummer and autumn with masses of bright rose colored flowers.

Spirea, Callosa Alba-A dwarf variety, with pure white flowers in great profusion.

Spirea, Prunifolia (Bridal Wreath)-Double daisy-like, pure white flowers in greatest profusion.

Spirea, Van Houttei-Finest of the Spireas, giving a complete mass of drooping white bloom.

Strawberry or Spindle Tree-These are large growing shrubs or small trees. Very pretty.

Sumach (Rhus)-Very popular among the large growing shrubs on account of the gorgeous colorings of foliage in autumn and the fact that they thrive in almost all soils.

Syringa (Mock Orange) Golden-leaved-A plant of medium size, with golden yellow foliage. It keeps its color the entire season; very sweet scented.

Syringa, Garland-A fine shrub with pure white, highly scented flowers; blooms early.

Syringa, Large-flowered-Very showy, large flowers, slightly scented.

Tamarix -A hardy shrub, with small delicate pink flowers in spikes. Valuable for the seaside where other shrubs will not grow.

Weigela, Candida-A strong, upright grower; flowers pure white; in great profusion in June.

Weigela, Rosea-A beautiful shrub, bearing rose-colored flowers in May and June.

Weigela, Variegated-Beautiful foliage, very ornamental.

Xanthoceras Sorbifolia-A fine upright shrub from China, with white and reddish-blown flowers in May. Very free flowering and beautiful; must be protected when young.

\section{EVERGREEN SHRUBS.}

Box, Tree-A handsome shrub with deep green foliage; requires protection.

Box, Dwarf-The well known edging plant.

Rhododendron or Rosebay-Magnificent flowering evergreen shrubs. They do best in a peaty soil, somewhat shaded, and require winter protection in exposed situations.

Yucca-A magnificent flowering plant, with large bell-shaped white flowers, borne ou a strong stem 2 feet high, in July. 


\section{CLEMATIS.}

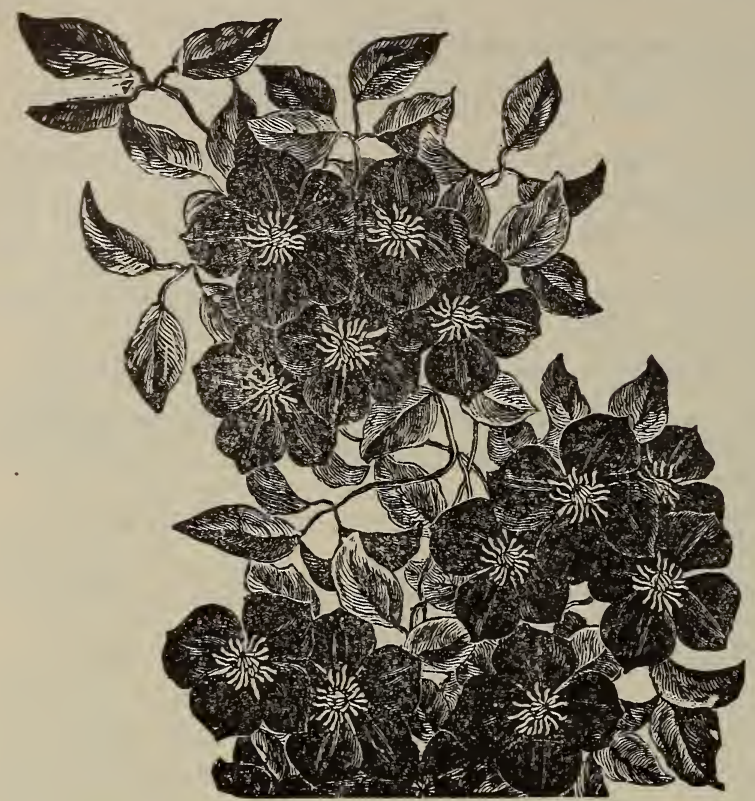

As a climbing vine the Clematis has no equal. Its great rich masses of flowers and rapid growth combine to make it the most desirable flower for veranda, screens, walls, arbors, etc. It requires good, deep sandy loam, well enriched.

Coccinea-Scarlet Clematis; flowers small, bell shaped, rich, deep scarlet.

Flammula-Flowers small, white, very fragrant.

Henryii-Single. The finest whiteClematis. Very large fine flowers; grows rapidly. Blooms freely during summer and autunin.

Duchess of Edinburgh-Double, pure white. Very fine.

Jackmanni-Single. Very large; deep purple; forms a perfect mass of the richest bloom; rapid grower and the very best purple sort.

Jackmanni Alba-Fine, large, pure white flowers. Growth similar to Jackmanni.

Kermesina-A beautiful variety; flowers about two-thirds the size of Jackmanni; a rapid grower; color, a bright wine-red; brilliant and beautiful.

Mme. Baron Veillard-A new Clematis, similar to Jackmanni except the flowers are a unique shade of soft pink. Very beautiful.

Mad. Ed. Andre-Flowers medium size, deep crimson-red; velvety; very free flowering, continuing during summer. Distinct and fine.

Paniculata-Single. White, of extremely rapid growth, with dark, shining green foliage, and a profusion of flowers which are small, but borne in large panicles. Very popular.

Romona-Deep sky blue; very attractive; equal to Jackmanni; new and valuable.

Virginiana-A strong grower, having fragrant white flowers followed by long woolly tufts.

other named sorts can be supplied if desired.

\section{CLIMBING VINES.}

Actinidia Arguta-A valuable Japanese climber, with handsome foliage. Flowers white with purple center, followed by an edible fruit of fine flavor.

Actinidia Polygama (Silver Sweet Vine)-Another hardy Japanese climber of remarkable beauty. Foliage at end of flowering shoots is of silvery-white color. Flowers are creamywhite with yellow anthers having a lily-of-the-valley fragrance.

Akebia Quinata-A charming Japanese climber with chocolate-colored flowers in June.

Ampelopsis (Japan Ivy)-For covering buildings of brick or stone; for churches, walls, etc., requires no support, clings tightly to the smoothest surface. Bright green leaves changing to brilliant colorings in autumn. It has no equal.

Ampelopsis Quinquefolia (Virginia Creeper or American Ivy)-A native climber of vigorous and luxuriant growth.

Aristolochia Sipho (Birthwort or Dutchman's Pipe)-A rapid-growing vine with magnifcent foliage and curious pipe-shaped brown flowers.

Bignonia (Trumpet Flower)-A vigorous climber, with scarlet flowers in August.

Cinnamon Vine-A beautiful, rapid grower, producing sweet-scented flowers.

Honeysuckle (Hall's Japan)-Almost evergreen, with pure white flowers, turning to yellow; very fragrant; vigorous, covered with flowers from July to December.

Honeysuckle (Monthly Fragrant)-Flowers red and pale yellow; sweet scented.

Honeysuckle (Scarlet Trumpet)-Flowers deep red, trumpet-shape; blooms all summer.

Ivy, Irish-A fine climber for north side of buildings.

Matrimony Vine-A pretty and rapid-growing vine, used for screens, etc.; perfectly hardy.

Passion Vine (Passiflora)-A rapid grower, well adapted for house culture in winter training over porches in summer, bearing very singular purple flowers.

Wistaria, Chinese Purple-One must see this plant in bloom to appreciate its magnificen

Perfectly hardy; it flowers in spring in long drooping racemes; very beautiful.

Wistaria. Chinese White-Similar to above except in color. 


\title{
HARDY PERENNIAL PLANTS.
}

\author{
For Permanent Planting in Borders, Beds, Cemetery Lots, Etc.
}

There is an ever-increasing demand for plants that are perfectly hardy and do not have to be taken up in the fall and replaced in the spring; and to meet the growing demand we offer a choice selection of sorts which exhibit the greatest contrast of colors, profusion of bloom, diversity of height and periods of bloom, so that a succession from early summer until frost. with the most picturesque effects, may be obtained.

Achillea (Yarrow)-Flowers borne in the greatest profusion the entire summer on strong erect stems, pure white, resembling pompon chrysanthemums.

Althea (Hollyhock)-For planting in masses or for background for lower growing plants, the Hollyhock is indispensable. We offer both double and single, in white, yellow, crimson and pink.

Amaryllis-Valuable alike for house, conservatory or garden. Flowers in clusters on a stalk 18 to 24 inches high. Attractive colors and variations.

Anemone-Nothing more beautiful in the entire list of hardy plants. Commence blooming in August and increase in beauty until frost. Colors white, rose and pink; single and semidouble.

Aquilegia (Columbine)-A grand flower for the border or rockery, embracing a variety of beautiful colors.

Arundo (Reed (Trass)-Especially ornamental planted in clumps in any position, their gigantic reed-like foliage giving a sub-tropical effect to the landscape. Foliage both plain and variegated.

Asters-Showy, hardy plants, graceful in habit and profuse bloomers, making an exceedingly pleasing appearance when massed in borders. White, blue and purple flowers.

Campanula (Bell Flower, Canterbury Bells)-Among the most valuable of our hardy plants. Colors light and dark blue and white.

Carnations-The delight of every one who has an eye for beauty in flowers. We offer a choice assortment in many shades, all beautifully fringed and fragrant.

Convallaria (Lily of the Valley)-A charming early spring flower, delightfully fragrant. Thrives in a shady situation where few other plants would grow.

Coreopsis lanceolata-Large, yellow, daisy-shaped flowers on long stems.

Desmodium (Sweet Pea Shrub)-Very showy and beautiful shrub which dies down every winter, but annually makes vigorous new growth, and is loaded in autumn with gracefully bending masses of pea-like $\mathrm{f}$ s.rers in white, red and violet.

Delphinum (Larkspur)-Bold, attractive plants, with long flower spikes of pleasing colors.

Dianthus (Pinks)-Valuable $d$ warf hardy plants that will increase in beauty from year to year. They have a delightful, clove-like fragrance, and range in colors from white to reddish purple and variegated. Prized for cut flowers.

Dicentra or Dielytra (Bleeding Heart)-A fine border plant, with rose-colored heart-shaped flowers.

Digitalis (Foxglove)-Broad foliage and towering showy spikes of bloom, varying from white to purple, affording fine effect in the border.

Doronicum (Dogbane)-One of the earliest flowering plants, with bright golden-yellow flowers.

Eulalias-Stately ornamental grasses that for the decoration of lawn or border have few equals.

Erianthus (Ravenna Grass)-A fine foliage grass resembling Pampas grass. Grows 6 to 8 feet and blooms abundantly. Excellent for decorating lawns or borders.

Funkia (Plantain Lily)-Plants of merit, thriving in any ordinary soil or situation, having attractive leaves, both plain and variegated, and white, yellow and lavender or violet lily-like flowers.

Gaillardia (Blanket Flower)-Very brilliant; blooms from early summer until frost.

Coranium (Crane's Bill)-Of great value in the garden; bloom freely and are easily grow Colors range from pink to purple. Attractive foliage. 
Helianthus (Perennial Sunflower)-Large, showy, bright sellow free-blooming perennials, both single and double. Tery fine for planting in masses in the shrub border, also valuable for cutting.

Helleborus (Christmas or Lenten Roses)-For cutting purposes in midwinter or early spring they are invaluable. Flowers white and reddish-purple. When once established they should not be disturbed.

Hemerocallis (Day Lil 5 )-Fine tall-growing plants, with large lily-shaped sweet-scented rellow flowers in early summer. Tery useful and desirable.

Hibiscus (Mallow)-Magnificent hardy decorative plants, with immense show $\mathbf{y}$ wite or rosecolored blossoms. The most popular sort is called "Crimson Eve," being pure white with rich relrety-crimson centre.

Hypericum Moserianum (St. John's Wort)-This is the finest variety of the whole family, flowers being nearly three inches across. Orange-yellow petals with red stamens.

Iberis (Candrtuft)-Finest of spring flowers; dark evergreen foliage surmounted by closebeads of pure white fowers.

Iris, German (Fleur de Lis)-The national flower of France. In beauty the flowers rival the finest orchids, colors running through the richest hues and erery imaginable shade.

Iris, Kæmpferi (Japanese)-Finest of the Iris family. Flowers 6 to 8 inches in diameter, and of the most beautiful shades and colors. Should be plentifully supplied with water.

Lathyrus (Perennial Pea)- When well established these give a continuous suppls of flowers. Colors white, red and pink. Fine for trellises or to scramble orer rocks, etc.

Lilies- We have a choice collection that will thrive in any dry rich soil where water will not stand in winter, and may be planted in the fall or spring, same as the other hardy plants here listed. After planting they require very little care, and should not be disturbed for years. Colors range from pure white to deepest scarlet. Named sorts furnished if desired.

Lychnis-Tothing in hardy plants gires a finer display of scarlet flowers. Fine for cutting.

Myosotis (Forget-me-not)-Small plants, with clusters of delicate blue flowers.

Pæonies-Fine hardy plants, rivaling the rose in perfection of bloom and coloring, and requiring little care, as they thrire and do well in any soil. Colors range from pure white to deep crimson.

Pæonia, Fringe-leaved (Tenuifolia)-Beautiful foliage in thread-like filaments; flowers very double, of dark satiny crimson color. Rare and exquisitely lovely.

Papaver Nudicaule (Iceland Poppy) - A beautiful class, forming ornamental tufts of fern-like foliage from which the flower stalk rises, bearing beautiful cup-shaped flowers in pure white, yellow and orange, and haring a pleasant lilac perfume.

Papaver Orientale (Oriental Poppy)-Tery large and brilliant deep red flowers produced on stout leafy stems 2 to 3 feet high. One of the best.

Phlox (Hards)-Tery fine; perfectly hardy; beautiful plants. Purple, lilac, pink and white.

Platycodon (Chinese Bell Flower)-Blooms constantly from July until October. Solitare white or blue flowers at the ends of the branches. Makes a dense branching bush 2 to $3 \mathrm{ft}$. high.

Potentilla (Cinquefoil)-An interesting class of perfectly hardy rock or border plants of dwarf or slightly trailing habit that produce an abundance of single, double or semi-double flowers of velvety texture and brilliant colors rarying from richest shades of vellow to deepest crimson.

Pyrethrum (Feverfew) - An excellent autumn-blooming plant, 3 to $4 \mathrm{ft}$. high, forming an immense branching head of bloom. Pure white with bright yellow centers. Valuable for cut flowers.

Ranunculus (Buttercup)-One of the best early spring flowers, unrivaled for lorely form and bright attractive colors and rariegations. Also makes an excellent house plant.

Rudbeckia, Golden Glow Flower (Summer Chrysanthemum)-A glorious, hardy flowering plant, producing an immense show of golden-yellow flowers in July. Grows 6 to 8 feet high.

Spirea, Blue (Caryopteris Mastocanthus)-Of handsome, rigorous growth, producing a profusion of rich skJ-blue flowers from midsummer until frost. Valuable for bedding or pot culture.

Spirea Japonica-Extensirels used for cut flowers. Flowers creamy white.

Spirea Palmata (Crimson Meadow Sweet)-Stems and branches reddish, flowers crimsonpurple.

Tritoma Uvaria (Flame Flower)-An attractire summer and autumn flowering plant, producing tall spikes of bright orange-red flowers. Should be protected with litter in winter.

Vinca (Myrtle)-Of creeping habit, evergreen foliage and bright flowers of blue or white; finely adapted to corer spots where grass will not grow.

Viola (Violets) - The hards forms of this dwarf and fragrant species are easily grown in the border, and ought to be more generally cultivated. Flowers white, blue and purple, double and single. 


\section{ROSES.}

Our Roses are strong dormant plants grown out doors, well rooted and in every way first-class. They have in most cases already bloomed before being sent out and we believe will give satisfaction and permanent success.

\section{THE FINEST OF THE OLD SORTS.}

Alfred Colomb-Bright crimson; very large.

American Beauty-Large, deep rose; very double with a delightful fragrance.

Anne de Diesbach-A lovely shade of pink.

Baron de Bonstetten-Rich, dark red.

Baroness Rothschild-A beautiful light pink, cupped form. The finest exhibition rose.

Bon Silene-Deep rose; equally valuable for summer or winter blooming.

Caprice-Petals beautifully striped pink and red.

Caroline de Sansal-Pale flesh, deepening toward centre; large, full, flat form. A lorely rose; blooms well in autumn.

Catharine Mermet-Light silvery-pink; one of the finest roses grown. Buds large and beautiful.

Charles Lefebvre-Reddish-crimson; very velvety and rich; large, full and handsomely formed.

Comtesse de Serenye-Silvery-pink, often mottled; full, finely shaped globular flowers. Reaches perfection late in the season.

Coquette des Alps-One of the finest pure white roses; full and finely formed; profuse bloomer; hardy and beautiful.

Coquette des Blanches-Pure white or slightly tinged with pink; medium size, flat and full, growth bushy and symmetrical; fine.

Duchess de Brabant-Light carmine tinged with violet.

Duke of Albany-Vivid crimson changing to velvety black; large and full; a free autumnal bloomer.

Devoniensis-Creamy-white, delicately flushed in centre with pink. One of the most fragrant roses.

Etoile de Lyon-Handsome chrome-yellow. One of the finest yellow bedding roses.

Eugene Verdier-Beautiful silvery-pink tinged with fawn; exquisite buds and large lustrous foliage; a beautiful rose.

Francois Michelon-Deep carmine rose; large, full and globular; free bloomer and fragrant; habit erect.

Gen. Jacqueminot-Crimson; rich and fine.

Gen. Washington-Bright crimson.

Gloire de Margottin-Brilliant scarlet; fine.

Harrison's Yellow-The best yellow.

Jean Liabaud-Crimson-maroon; large, full and fragrant.

John Hopper-Bright pink; full.

Louis Van Houtte-Rich deep crimsou.

La France-Delicatesilvery-rose, shaded with pink. Very large; superb form.

La Reine-Bright rose; large, full, free flowering.
Mabel Morrison-White or tinged with blush A very valuable white rose.

Mad. Gabriel Luizet-Pink; very large and fragrant, cup shaped, rich and full.

Mad. Hoste-Color varies from ivory-white to canary-yellow; vigorous and abundant bloomer.

Mad. Plantier-White; very free blooming.

Mad. Victor Verdier-Crimson-c(armine; full and fragrant.

Magna Charta-Bright clear pink.

Marchioness of Lorne-Rich rose shaded with vivid carmine. Buds long and handsome; an almost continuous bloumer.

Marie Baumann-Brilliant crimson; large, full and fragrant.

Marie Rady-Vermilion, shaded crimson; globular; fragrant.

Marshall P. Wilder-Bright cherry-carmine; fragrant; vigorous, fine form.

Niphetos-Snowy-white; long pointed buds. Not suitable for out-door culture.

Papa Gontier-A fine crimson Tea and one of the best for all purposes.

Paul Neyron-Deep rose; double; large size.

Perle des Jardins-Beautiful straw to deep canary; fine form; free flowering.

Persian Yellow-Deep golden-yellow; hardy.

Pierre Notting-Deep maroon. A superb dark rose.

Prince Camille de Rohan-Deep velvety crim. son. A splendid rose.

Safrano-Saffron and apricot. An old favorite.

Sombreuil-White tinged with rose; blooms in clusters.

Sunset-Saffron shaded with orange; double and handsome.

Victor Verdier-Bright rose, carmine centre; beautiful.

\section{Climbing Roses.}

Baltimore Belle- White tinged with blush; very double; flowers in clusterf

Queen of Prairie-Rosy red; flowers largo and compact. Very popular.

\section{Moss Roses.}

Blanche Moreau-White; the finest white Mosa Common-Red.

Crested-Pale pink buds; very beautiful.

Perpetual Pink, Red, White-Old favorites.

Princess Adelaide-Pale rose; fine.

Salet-Red; an old favorite.

William Lobb-Red. 


\section{HYBRID SWEET BRIARS OR “LORD PENZANCE” ROSES.}

These are crosses between the common Sweet Briar and other roses. The flowers are single, beautiful and interesting. The foliage is sweet scented. We can supply them in Rose, Pink, Crimson, White and Copper color. They are perfectly hardy, standing 22 degrees below zero.

\section{TREE ROSES.}

The Tree Roses are grafted on hardy rose canes four to five feet high, are tree shaped, and when in full bloom are objects of beauty, making handsome plants for the lawn. They need winter protection.

We can supply White, Red, Pink, Yellow and Crimson, named varieties, very fine, strong trees that will bloom the first year.

Rosa Rugosa-Of Japanese origin; flowers mostly single; plant very beautiful on account of its good habit and beautiful glossy foliage; colors, white and rosy crimson.

Madam George Bruant-A distinct variety of above; flowers in clusters; pure white, buds long and pointed.

Wichuraiana or Memorial Rose-4 trailing species, valuable for covering banks, rockeries, etc., and for use in cemeteries. Pure white, $1 \frac{1 / 2}{2}$ to 2 inches across and strongly fragrant.

\section{THE NEWER ROSES.}

Bride-Pure white; fine form; fragrant, tender. Bridesmaid-Deep, clear pink; tender.

Clothilde Soupert-A new Tea Polyantha. Flowers in clusters; perfectly full and double, and deliciously fragrant; shades from ivory white to silvery rose; very beautiful.

Clio-Flesh color. Perfection in form and growth; fine, broad petals; delicate texture; prolific bloomer; very fine.

Crimson Rambler-Flowers a rich glowing crimson, bright and clear, and remain on the plant in perfect condition, with their freshness and beauty unimpaired, for more than two weeks. They are borne in immense clusters. Entirely hardy. Awarded three gold medals.

Pink Rambler, White Rambler and Yellow Rambler are similar in growth to the above, but not quite as rampant growers nor so hardy, but very pretty used in combination with it.

Baby Rambler-A dwarf variety in Crimson, Pink, White and Yellow. Constant bloomers. Dorothy Perkins-A beautiful pink variety of the Rambler. Hardy and desirable.

Philadelphia Rambler-An improved variety of the Crimson Rambler.

Climbing American Beauty - A strong growing variety of the American Beauty type. A valuable addition to the rose family.

Lady Gay-Flowers in large, loose clusters of a delicate cherry-pink, fading to a pearlywhite. Perfectly hardy.

Tausendschon or Thousand Beauties - A very handsome, strong growing climber, bearing clusters of large delicate pink flowers shading to white. Very beautiful.

Gruss an Teplitz-Large, rich scarlet, shading to crimson. Flowers profusely all summer.

Killarney-One of the most popular of our garden roses, and one of the leading varieties for cut flowers. Blooms large, brilliant pink, with long pointed buds.

Frau Kar: Druschki, or Snow Queen-An exquisite new rose, absolutely pure white.

Mrs. R. G. Sharman-Crawford-Deep rosy pink, shaded with flesh. Blooms all summer.

Earl of Dufferin-Rich, brilliant, velvety crimson, shaded with dark maroon; large, full, finely formed; delightfully fragrant.

Fisher Holmes-Large, crimson, vigorous and free flowering. Resembles Gen. Jacqueminot, but fuller, darker and better bloomer.

Francois Levet-Fresh, clear, rose color, bright and glistening. Large; fine form; free Rowering.

Golden Gate-Creamy-white tinged with flesh; large and nicely formed. Beautiful.

Jubilee-A grand new rose; large; deep red, changing to crimson and velvety maroon.

Kaiserin Augusta Victoria-Delicate creamy-white with exquisite fragrance. Beautiful buds.

Liberty-One of the handsomest dark red roses. Resembles Meteor.

Marchioness of Londonderry-Color irory white; petals shell-shaped, reflexed; highly perfumed, free flowering. Very fine. Awarded gold medal.

Margaret Dickson-This beautiful rose cannot be too highly recommended. It is white, with pale flesh center; petals very large, shell-shaped and of great substance; fragrant; foliage very large, dark green; a very strong grower.

Meteor-A very beautiful deep velvety crimson. A grand rose.

Mrs. John Laing-Delicate salmon pink, fine form, very fragrant; blossoms continuously through the summer; one of the finest pink roses.

UIrich Brunner-Brilliant cherry red, fine form and finish; petals of great substance; vigorous, hardy; one of the best. 
FRUITS.

Apples............ Fage

Apricots.................

Blackberries................. 19

Cherries............... 8

Garden Roots . ................ 15

Gcoseberries................ 16

Grapes.................. 14

Nectarines................ 12

Nut Trees.............. 13

Peaches................ 11

Plums................. 9, 9,

Quinces.

Raspberries.

12
7,18

20

ORNAMENTAL TREES.

Ailanthus.

Alder.

Ash......

Basswood.

Buttonwood.

Beech

Birch.... . .

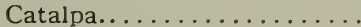

Cedrela Sinensi

Cherry.

Crab.....

Elms...

Golden Chain

Horse Chestnut.

Judas Tree.

Laburnum

Larch.

Liquidambar

Magnoila...

Maiden Hair .

Maples...

Mountain Ash

Mulberry.

Oaks.

Double-flowering .... 23

Pissardi, Prunus.......... 23

Flane.................. 23

Plum, Purple-leaf........... 23

Poplar............... 23

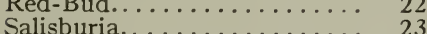

$\begin{array}{ll}\text { Salisburia................ } & 23 \\ \text { Sweet Gum............ } & 23\end{array}$

Sycamore............. 23

Tulip Tree............ 23

Thorn

Tree of Heaven.............. 23

Walnut............... 23

Whitewood............... 23

Willows.

Yellow Wood............... 23

EVERGREENS.

Arbor Vitae

Hedging-Deciluous an $]^{\cdots} \quad 24$

$$
\text { Evergreen........................ }
$$

Juniper..........

Pine..

Thuja Occidentalis...........

ORNAMENTAL SHREES.

Almond.

Althea

. 25

Angelica Tree............... 25

Aralia.

Azalea.

Barberry

Bladder Senna.

Bridal Wreath.

Broom.

Calycanthus.

Clematis.

Clethra Alnifolia

Corchurus.
ORNAMENTAL SHRUBS-Con.

Cornus ................. Page

Coronilla................ 25

Currant, Flowering............ 25

Cydonia Japonica............ 27

Daphne............... 25

Dwarf Horse Chestnut......... 27

Elder.

Eleagnus Longpipes.......... 26

Exorchorda.

Filbert, Purple-leaf......... 26

Forsythia.............. 26

Fringe. ............... 26

Garland Flower............. 25

Genista................ 25

Golden Bell ................ 26

Halesia. .............. 27

Hedysarum.

Hercules Club

High Bush Cranberry.

Honeysuckle.

Hydrangea.

Kerria Japonica.

Lilacs.

Limonia Trifoliata

Mock Orange.

Orange, Hardy

Otaheite Orange

Opulis. . .

Paeonias.

Pavia

Pearl Bush

Prunet, California......... 27

Quince.

Rhus.

Rose of Sharon

Sambucus Aurea

Scorpion Senna.

Silver Bel . .

Snowball.

Snowdrop Tree.

Spireas

Sumach...

Sweet Pepper Bus

Sweet-Scented Shrub.

Syringa....

Tamarix

Viburnum

$\begin{array}{ll}\text { Weigela......................... } & 27 \\ \text { Xanthoceras Sorbifolia ..... } & 27\end{array}$

EVERGREEN SHRUBS.

Box, .............................

Yucca Filamentosa...

\section{CLIMBING VINES.}

Actinidia

Akebia Quinata.

Ampelopsis. .

Aristolochia Sipho

Birnonia.

Birthwort or Dutchman's Pipe..

Cinnamon Vine........... 28

Honeysuckle. ........... 28

Ivy................. 28

Matrimony Vine.......... 28

Passiflora ............... 28

Silver Sweet Vine.......... 28

Trumpet Flower ......... 28

Virginia Creeper........... 28

Wistaria.

28

HARDY PERENNIAL PLANTS.

Achillea................ 29

Althea.................. 29

A maryllis................ 29

Anemone............. 29

Aquilegia............. 29

Arundo.

\section{HARDY PERENNIAL PLANTS} Continued.

Asters ..................... Page

Bell Flower............... 29

Blanket Flower............ 29

Bleeding Heart.......... 29

Buttercup. . . . . . . . . . 30

Campanula ............. 29

Candytuft.............. 30

Canterbury Bells............ 29

Carnations.............. 29

Caryopteris Mastacanthus... 30

Chinese Bell Flower...... 30

Christmas Rose.............. 30

Cinquefoil............ 30

Columbine............. 29

Convallaria........ 29

Coreopsis lanceolata......... 29

Crane's Bill............... 29

Crimson Meadow Sewet.... 30

Desmodium .

Delphinium .......................... 29

Dianthus................. 29

Dicentra or Dieltyra......... 29

Digitalis............. 29

Dogbane............... 29

Doronicum.............. 29

Eulalias................ 29

Erianthus.............. 29

Fleur de Lis................. 30

Forget-me-not............. 30

Foxglove.............. 29

Funkia................ 29

Flame Flower........... 30

Gaillardia............... 29

Geranium................ 29

Golden Glow Flower......... 30

Helianthus............. 30

Helleborus . . . . . . . ...... 30

Hemerocallis............ 30

Hibiscus. . . ......... 30

Hollyhock................ 29

Hypericum Moserianum ..... 30

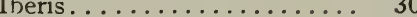

Iris . .............. 30

Larkspur............... 29

Lathyrus............. 30

Lenten Rose............ 30

Lilies . Rose................. 30

Lily of the Valley........... 29

Lychnis............... 30

Mallow............... 30

Myosotis.............. 30

Myrtle............ 30

Paeonies.............. 30

Papaver................ 30

Perennial Pea ............ 30

Perennial Sunflower......... 30

Phlox. 30

Pinks................... 29

Plantain Lily................. 29

Platycodon............. 30

Poppy.................. 30

Potentilla................ 30

Pyrethrum............... 30

Ranunculus............. 31

Ravenna Grass..............

Rudbeckia................. 30

Spireas................. 30

St. John's Wort............ 30

Sweet Pea Shrub............ 29

Tritoma Uvaria........... 30

Vinca . ................ 30

Viola................... 30

Violets.

Yarrow.

ROSES.

All varieties. ROS. ....31,32

MISCELLANEOUS.

Directions for Transplanting

2nd p. cover 
